\title{
Stable isotopic composition of deep-sea gorgonian corals Primnoa spp.: a new archive of surface processes
}

\author{
Owen A. Sherwood ${ }^{1, *}$, Jeffrey M. Heikoop ${ }^{2}$, David B. Scott ${ }^{1}$, Michael J. Risk ${ }^{3}$, \\ Thomas P. Guilderson ${ }^{4,5}$, Richard A. McKinney ${ }^{6}$ \\ ${ }^{1}$ Centre for Environmental and Marine Geology, Dalhousie University, Halifax, Nova Scotia B3H 4J1, Canada \\ ${ }^{2}$ Los Alamos National Laboratory, EES-6, MSD462, Los Alamos, New Mexico 87545, USA \\ ${ }^{3}$ School of Geography and Geology, McMaster University, Hamilton, Ontario L8S 4M1, Canada \\ ${ }^{4}$ Center for Accelerator Mass Spectrometry, Lawrence Livermore National Laboratory, Livermore, California 94551, USA \\ ${ }^{5}$ Department of Ocean Sciences \& Institute of Marine Sciences, University of California Santa Cruz, Santa Cruz, California 95064, USA \\ ${ }^{6}$ United States Environmental Protection Agency, Atlantic Ecology Division, Narragansett, Rhode Island 02882, USA
}

\begin{abstract}
The deep-sea gorgonian coral Primnoa spp. live in the Atlantic and Pacific Oceans at depths of 65 to $3200 \mathrm{~m}$. They have an arborescent growth form with a skeletal axis composed of annual rings made from calcite and gorgonin. Lifespans may exceed several hundreds of years. It has been suggested that isotope profiles from the gorgonin fraction of the skeleton could be used to reconstruct long-term, annual-scale variations in surface productivity. We tested assumptions about the trophic level, intra- and inter-colony isotopic reproducibility, and preservation of isotopic signatures in a suite of modern and fossil specimens. Measurements of gorgonin $\delta^{15} \mathrm{~N}$ indicate that Primnoa spp. feed mainly on zooplankton and/or sinking particulate organic matter $\left(\mathrm{POM}_{\text {sink }}\right)$, and not on suspended POM (POM ${ }_{\text {susp }}$ ) or dissolved organic carbon (DOC). Gorgonin $\delta^{13} \mathrm{C}$ and $\delta^{15} \mathrm{~N}$ in specimens from NE Pacific shelf waters, NW Atlantic slope waters, the Sea of Japan, and a South Pacific (Southern Ocean sector) seamount were strongly correlated with surface apparent oxygen utilization (AOU; the best available measure of surface productivity), demonstrating coupling between skeletal isotopic ratios and biophysical processes in surface water. Time-series isotopic profiles from different sections along the same colony, and different colonies inhabiting the same area were identical for $\delta^{13} \mathrm{C}$, while $\delta^{15} \mathrm{~N}$ profiles were less reproducible. Similarity in $\mathrm{C}: \mathrm{N}, \delta^{13} \mathrm{C}$ and $\delta^{15} \mathrm{~N}$ between modern and fossil specimens suggest that isotopic signatures are preserved over millennial timescales. These results support the use of Primnoa spp. as historical recorders of surface water processes such as biological productivity and the isotopic composition of source nutrients.
\end{abstract}

KEY WORDS: Primnoa $\cdot$ Gorgonin $\cdot \delta^{13} \mathrm{C} \cdot \delta^{15} \mathrm{~N} \cdot$ Trophic level $\cdot$ Paleoceanography

\section{INTRODUCTION}

Primnoa resedaeformis (Gunnerson) is a deep-sea gorgonian coral with known occurrences in North Atlantic, Arctic and North Pacific waters at depths of 65 to 3200 m (Breeze et al. 1997, Etnoyer \& Morgan 2003). A subspecies, P. resedaeformis notialis (Bayer), occurs on seamounts in the Southern Ocean sector of the Pacific Ocean. P. willeyi (Hickson) and P. pacifica (Kinoshita) are found in the eastern and western North Pacific, respectively (Smithsonian holdings:
http://goode.si.edu/webnew/pages/nmnh/iz/Query.php). These corals have an arborescent growth pattern with a skeleton made of calcite and a proteinaceous material called gorgonin (Goldberg 1976) arranged in alternating concentric rings around longitudinal growth axes (Risk et al. 2002, Sherwood 2002). Towards the outer growth surface of older portions of the skeleton the outer cortex may be comprised of just calcite, with gorgonin layers lacking. Based on ${ }^{210} \mathrm{~Pb}$-dating, Andrews et al. (2002) inferred that visible growth rings in the skeleton are formed annually. This 
was subsequently validated with bomb $-{ }^{14} \mathrm{C}$ (Sherwood et al. 2005, this volume). Subannual banding patterns have also been identified using scanning electron microscopy and Nomarski differential interference imaging (Risk et al. 2002, Sherwood 2002). This coral appears to have lifespans on timescales of up to several centuries (Andrews et al. 2002, Risk et al. 2002).

Based on ${ }^{14} \mathrm{C}$ analyses, Griffin \& Druffel (1989) originally suggested that the main source of carbon to deep-sea corals was sinking particulate organic matter $\left(\mathrm{POM}_{\text {sink }}\right)$. They further suggested (Druffel et al. 1995) that the carbon and nitrogen isotopic composition of the proteinaceous layers of the colonial zoanthid Gerardia sp. could be a recorder of surface ocean processes (productivity, nutrient sources, etc.). Primnoa spp. may also form their gorgonin skeleton from $\mathrm{POM}_{\text {sink, }}$ since $\delta^{13} \mathrm{C}$ and $\delta^{15} \mathrm{~N}$ in the polyps and gorgonin show similar regional differences to $\delta^{13} \mathrm{C}$ and $\delta^{15} \mathrm{~N}$ of surface water POM (Heikoop et al. 1998, 2002). Moreover, the $\delta^{13} \mathrm{C}$ and $\delta^{15} \mathrm{~N}$ of the polyps are highly correlated to the $\delta^{13} \mathrm{C}$ and $\delta^{15} \mathrm{~N}$ of associated gorgonin (Heikoop et al. 2002). Together, these results suggest that the isotopic composition of annual gorgonin layers could record the temporal history of processes that control the isotopic composition of POM (Heikoop et al. 2002) including plankton productivity and the $\delta^{13} \mathrm{C}$ and $\delta^{15} \mathrm{~N}$ of nutrient sources (e.g. Ward-Paige et al. 2005). The $\delta^{13} \mathrm{C}$ and $\delta^{15} \mathrm{~N}$ of gorgonin from a suite of corals from Alaskan waters, waters off the eastern shore board of the United States and Canada, and a South Pacific seamount were positively correlated (Heikoop et al. 2002), suggesting that surface ocean productivity relative to nutrient supply may be the primary control on the isotopic composition of gorgonin.

For stable isotope profiles generated from the annual gorgonin layers of Primnoa spp. skeletons to have any meaningful environmental significance, 4 conditions must be met: (1) the trophic position of Primnoa spp. must be known; (2) organic diagenesis must not affect the isotopic composition of the skeleton; isotopic trends must be reproducible among (3) different sections of the same colony and (4) different colonies inhabiting the same area. The purpose of this paper is to test these assumptions using a suite of recently collected live and fossil specimens from the Atlantic and Pacific Oceans.

\section{MATERIALS AND METHODS}

Specimens were obtained during research and fishing expeditions (Table 1). In addition, 7 specimens were obtained from the Smithsonian Institution National Museum of Natural History. Primnoa resedaeformis (Gunnerus) was collected from the NE Channel, SW of Halifax, Nova Scotia (Fig. 1), and from east of Virginia Beach, Virginia, USA. P. willeyi (Hick-

Table 1. Primnoa spp. Collection data of samples examined. n/a: not applicable

\begin{tabular}{|c|c|c|c|c|c|c|}
\hline Sample & Species & Location & $\begin{array}{c}\text { Year } \\
\text { collected }\end{array}$ & Lat. & Long. & $\begin{array}{l}\text { Depth } \\
(\mathrm{m})\end{array}$ \\
\hline \multicolumn{7}{|l|}{ NW Atlantic } \\
\hline ROPOS 637052 & P. resedaeformis (Gunnerus) & NE Channel & 2001 & $42.048^{\circ} \mathrm{N}$ & $65.577^{\circ} \mathrm{W}$ & 475 \\
\hline ROPOS 639009 & P. resedaeformis (Gunnerus) & NE Channel & 2001 & $41.998^{\circ} \mathrm{N}$ & $65.648^{\circ} \mathrm{W}$ & 410 \\
\hline HUD-2000-020-VG2 & P. resedaeformis (Gunnerus) & NE Channel & 2000 & $42.047^{\circ} \mathrm{N}$ & $65.610^{\circ} \mathrm{W}$ & 331 \\
\hline HUD-2001-055-VG-15 & 5 P. resedaeformis (Gunnerus) & NE Channel & 2001 & $42.021^{\circ} \mathrm{N}$ & $65.682^{\circ} \mathrm{W}$ & 321 \\
\hline DFO-2002-con5 & P. resedaeformis (Gunnerus) & NE Channel & 2002 & $42.0^{\circ} \mathrm{N}^{\mathrm{d}}$ & $-65.6^{\circ} \mathrm{W}^{\mathrm{d}}$ & $250-500$ \\
\hline COHPS-2001-1 ${ }^{\mathrm{a}}$ & P. resedaeformis (Gunnerus) & NE Channel & 2001 & $42.0^{\circ} \mathrm{N}^{\mathrm{d}}$ & $-65.6^{\circ} \mathrm{W}^{\mathrm{d}}$ & $250-500$ \\
\hline Fossil-95 ${ }^{\mathrm{b}}$ & P. resedaeformis (Gunnerus) & NE Channel & 1995 & $42.0^{\circ} \mathrm{N}^{\mathrm{d}}$ & $-65.6^{\circ} \mathrm{W}^{\mathrm{d}}$ & $250-500$ \\
\hline Smith-54269 & P. resedaeformis (Gunnerus) & East of Virginia Beach & 1974 & $37.060^{\circ} \mathrm{N}$ & $74.410^{\circ} \mathrm{W}$ & $237-385$ \\
\hline \multicolumn{7}{|l|}{ NE Pacific } \\
\hline QC-98 & P. willeyi (Hickson) & East of Queen Charlotte Islands & 1998 & $54.386^{\circ} \mathrm{N}$ & $132.786^{\circ} \mathrm{W}$ & 378 \\
\hline KIS-02 & P. willeyi (Hickson) & Knight Inlet sill, British Columbia & 2002 & $50.679^{\circ} \mathrm{N}$ & $126.000^{\circ} \mathrm{W}$ & 65 \\
\hline Smith-51283 & P. pacifica (Kinoshita) & Prince William Sound, Alaska & 1941 & $61.034^{\circ} \mathrm{N}$ & $146.714^{\circ} \mathrm{W}$ & 64 \\
\hline Smith-52199 & P. willeyi (Hickson) & Chatham Sound, British Columbia & 1960 & $54.5^{\circ} \mathrm{N}^{\mathrm{d}}$ & $130.5^{\circ} \mathrm{W}^{\mathrm{d}}$ & $\mathrm{n} / \mathrm{a}$ \\
\hline Smith-1010257 & P. willeyi (Hickson) & Atka Island, Alaska & 2002 & $51.9^{\circ} \mathrm{N}^{\mathrm{d}}$ & $174.1^{\circ} \mathrm{W}^{\mathrm{d}}$ & $213-220$ \\
\hline Smith-1010785 & P. willeyi (Hickson) & South of Chirikof Island, Alaska & 2000 & $55.5^{\circ} \mathrm{N}^{\mathrm{d}}$ & $155.5^{\circ} \mathrm{W}^{\mathrm{d}}$ & 235 \\
\hline \multicolumn{7}{|l|}{ Sea of Japan } \\
\hline $\mathrm{SOJ}-03$ & P. pacifica (Kinoshita) & South of Vladivostok, Russia & 2003 & $42.482^{\circ} \mathrm{N}$ & $132.572^{\circ} \mathrm{E}$ & 913 \\
\hline Smith-56993 & P. pacifica (Kinoshita) & West of Hokkaido, Japan & 1906 & $43.000^{\circ} \mathrm{N}$ & $140.175^{\circ} \mathrm{E}$ & $713-783$ \\
\hline \multicolumn{7}{|c|}{ S Pacific - Southern Ocean Sector } \\
\hline Smith-58171 & \multirow{2}{*}{\multicolumn{2}{|c|}{$\begin{array}{l}\text { P. resedaeformis notialis (Bayer) } \mathrm{S} \text {. Pacific seamount } \\
\text { P. resedaeformis notialis (Bayer) } \mathrm{S} \text {. Pacific seamount }\end{array}$}} & 1964 & $54.833^{\circ} \mathrm{S}$ & $129.833^{\circ} \mathrm{W}$ & 604 \\
\hline Smith-87624c & & & 1964 & $54.817^{\circ} \mathrm{S}$ & $119.800^{\circ} \mathrm{W}$ & 549 \\
\hline
\end{tabular}




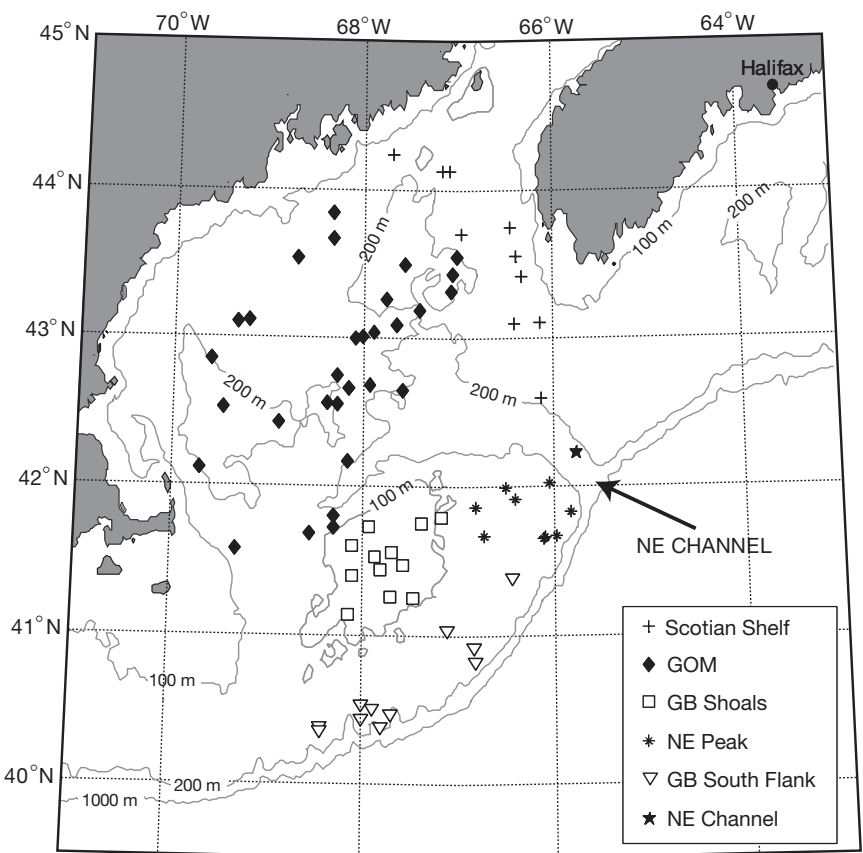

Fig. 1. Gulf of Maine (GOM) region, NW Atlantic Ocean. Colonies of Primnoa resedaeformis were collected from the NE Channel. Symbols show locations of water samples for analysis of suspended POM ( $\left.\mathrm{POM}_{\text {susp }}\right)$. GB: Georges Bank son) was collected east of the Queen Charlotte Islands, Chatham Sound and Knight Inlet, British Columbia, and from the Aleutian Islands and Prince William Sound, Alaska. P. pacifica (Kinoshita) was collected in the Sea of Japan. The subspecies $P$. resedaeformis notialis was collected from a seamount in the Southern Ocean sector of the South Pacific. Of the Smithsonian samples, 3 were originally reported in Heikoop et al. (2002); these are included here to highlight geographic trends in stable isotopic composition.

All specimens were collected alive, except for Colonies Fossil-95 and COHPS-2001-1. These deadcollected specimens were dated radiometrically by B. Ghaleb at GEOTOP-UQAM-McGill, Montreal, Canada (Scott unpubl. data). Samples from Colony COHPS-2001-1 are ca. 1850 AD, based on ${ }^{210} \mathrm{~Pb}^{-26} \mathrm{Ra}$ analyses of the outer calcite cortex region of the coral. Fossil-95 is ca. 200 AD, based on 2 uranium-series dates on the middle and outer regions of a section of the colony.

Colonies for stable isotope analyses (Fig. 2) were sectioned with a rock saw and ground and polished on a diamond lap wheel to a thickness of about $5 \mathrm{~mm}$. Sections were photographed with a Nikon Coolpix digital camera in macro-mode. After some trial and
Fig. 2. Primnoa resedaeformis. Colony collected from the NE Channel: (a) Colony HUD-2001-055VG15 (tissue missing); (b) Colony DFO-2002-con5 (tissue present). Boxes outline sections for isotopic timeseries profiles, tissue samples. Scale ruler $=15 \mathrm{~cm}$
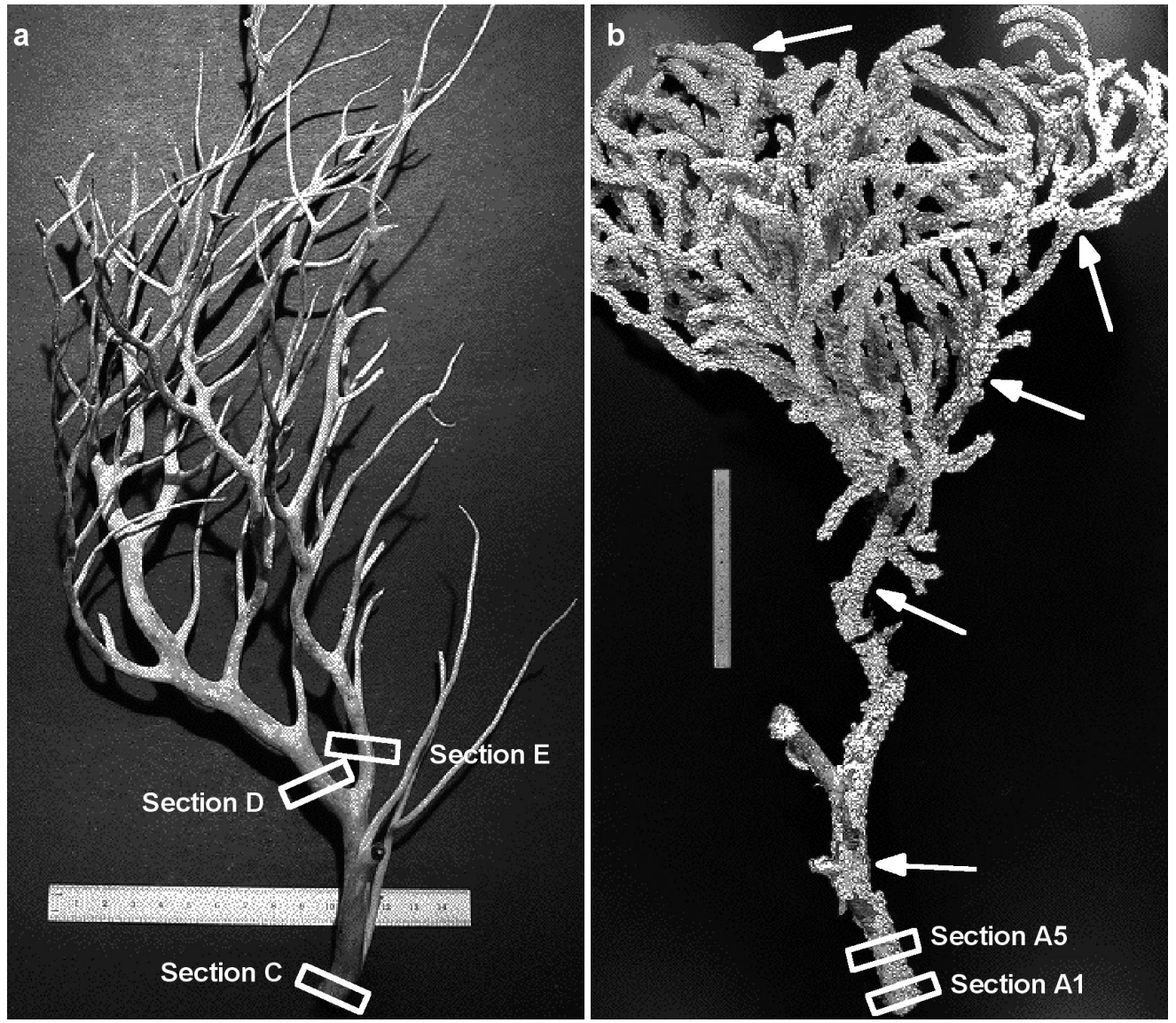
error we found that photographing the sections in ultraviolet light gave the clearest image of ring patterns in the horny axis owing to contrast between the calciterich (luminescent) and gorgonin-rich (non-luminescent) portions of the annual growth rings (Fig. 3).

Annual gorgonin rings were isolated by dissolving sections in $5 \% \mathrm{HCl}$ for $1 \mathrm{wk}$ (up to $3 \mathrm{wk}$ for larger sections). Upon dissolution, sections were transferred to a Petri dish filled with distilled water, and the annual rings were teased apart with tweezers and scalpel under a binocular microscope. Photographs of the sections taken before dissolution were used to guide sampling. Individual rings were placed in $5 \mathrm{ml}$ polyethylene vials with $5 \% \mathrm{HCl}$ for an additional week to ensure that all the calcite had dissolved. After 2 more

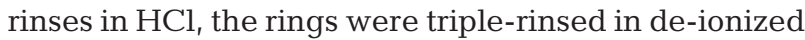
water and dried in a low temperature oven. Rings averaged about $5 \mathrm{mg}$ in weight. Tissue material scraped off the skeletal axes was prepared in the same way.

Isotopic and $\mathrm{C}: \mathrm{N}$ analyses of gorgonin were performed by elemental analyzer/continuous flow isotope ratio mass spectrometry at GEOTOP-UQAM-McGill. Isotope ratios are reported in conventional delta notation, where (example for carbon): $\delta^{13} \mathrm{C}=\left[\left(R_{\text {sample: }}\right.\right.$ : $\left.\left.R_{\text {standard }}\right)-1\right] \times 1000$; and $R={ }^{13} \mathrm{C}:{ }^{12} \mathrm{C}$. Standards used were PDB $\left(\delta^{13} \mathrm{C}\right)$ and air $\left(\delta^{15} \mathrm{~N}\right)$. Analytical error, as measured by the standard deviation of duplicate mea- surements, averaged $0.10 \%$ for $\delta^{13} \mathrm{C}$ and $\delta^{15} \mathrm{~N}$, and 0.01 for C:N. Some of the corals obtained from the Smithsonian Institute were preserved in ethanol, which may have affected stable isotope compositions (Bosley \& Wainright 1999).

Suspended particulate organic matter $\left(\mathrm{POM}_{\text {susp }}\right)$ in the Gulf of Maine/Georges Bank region (Fig. 1) was sampled as part of the Ecosystems Monitoring Survey at the Northeast Fisheries Science Center, Narragansett, Rhode Island, USA. Samples were collected in spring, summer and autumn, between November 2000 and August 2003. In addition, a vertical transect (depths of 3.7, 100 and $215 \mathrm{~m}$ ) was sampled in August 2004 in the NE Channel (Fig. 1). Surface samples were obtained with a ship-board, near surface flow-through system. Deeper samples were collected with Niskin bottles attached to a CTD rosette. A volume of 600 to $1000 \mathrm{ml}$ of water was pre-filtered through $300 \mu \mathrm{m}$ mesh to remove most zooplankton, and then onto a GF/F filter. Samples were immediately frozen and transported to the US Environmental Protection Agency, Atlantic Ecology Division, Narragansett, for isotopic analysis. Carbon and nitrogen isotope composition was determined by continuous flow isotope ratio mass spectrometry using a Carlo-Erba NA 1500 Series II elemental analyzer interfaced to a GV Instruments Optima mass spectrometer. All samples were analyzed

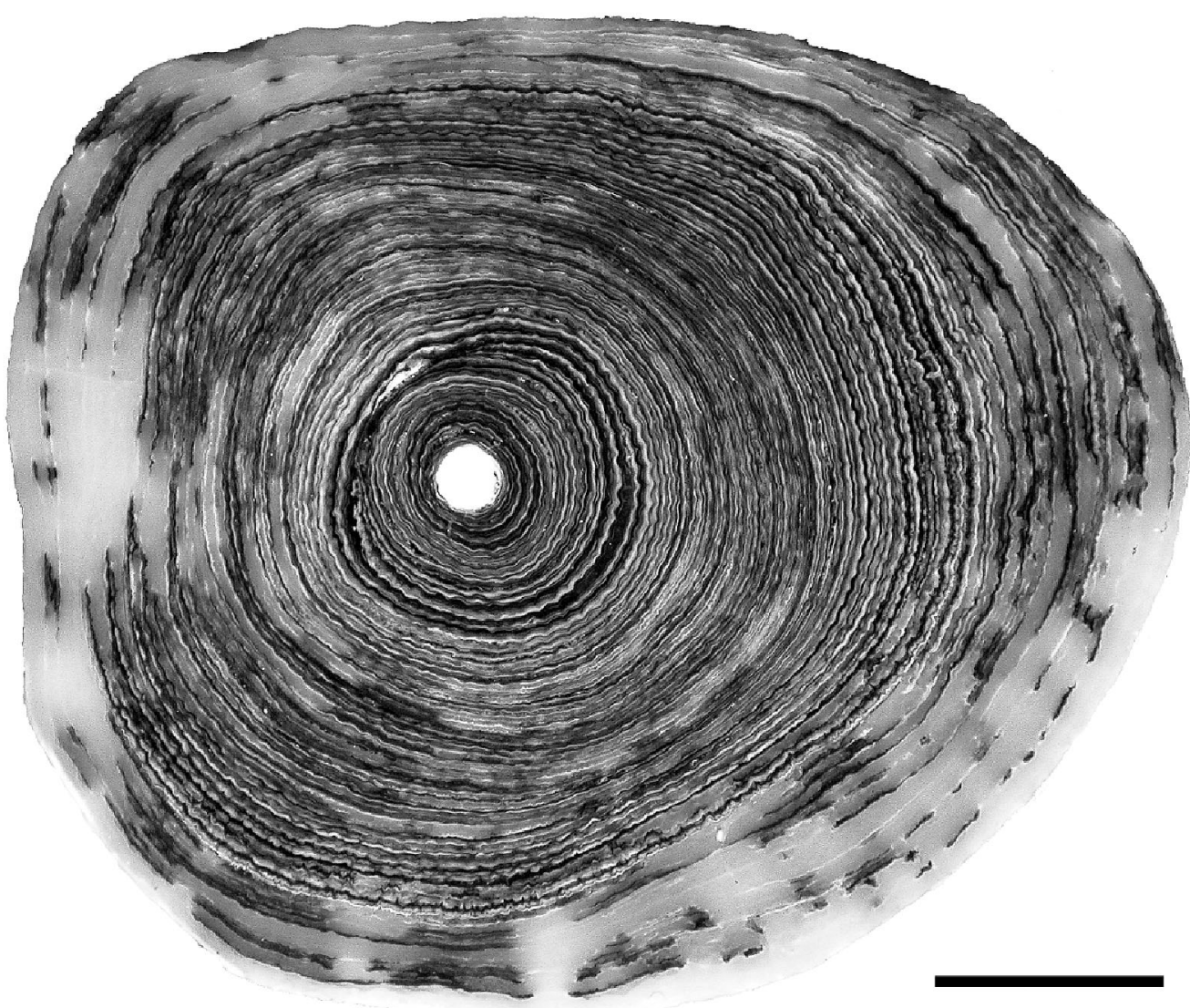

Fig. 3. Primnoa resedaeformis. Section A5 from Colony DFO-2002-con5, photographed under ultraviolet light. Gray portion of outer section is the inorganic calcite cortex; darker layers towards middle are annual gorgonin rings isolated for chemical analyses. Based on growth ring counts, specimen is approx. 75 yr old (Sherwood et al. 2005). Scale bar = $0.5 \mathrm{~cm}$ 
in duplicate with a typical difference of about $0.1 \%$. Sample material was re-analyzed periodically over a period of several months and exhibited a precision of $0.30 \%$, calculated as a single sigma standard deviation of all replicate values. This latter estimate of precision is appropriate for $\mathrm{POM}_{\text {susp }} \delta^{15} \mathrm{~N}$ values determined in this study.

\section{RESULTS}

\section{Composition of tissue and skeletal gorgonin}

Stable isotope and C:N data for Primnoa spp. are summarized in Table 2. There were large differences in the isotopic and elemental composition between tissue and gorgonin. $\mathrm{C}: \mathrm{N}$ ratios were higher and more variable in tissue $(6.1 \pm 1.4, \mathrm{n}=11)$ than gorgonin $(3.3 \pm$ $0.1, \mathrm{n}=8) . \delta^{13} \mathrm{C}$ values were more negative in the tissue by an average of $3.0 \pm 1.7 \%$ o $(n=9)$. Most of this difference in $\delta^{13} \mathrm{C}$ may be accounted for by the difference in lipid content of the 2 fractions. Taking $\mathrm{C}: \mathrm{N}$ as a proxy for lipid content, lipid-normalized values of $\delta^{13} \mathrm{C}\left(\delta^{13} \mathrm{C}^{\prime}\right)$ were calculated from equations in McConnaughey \& McRoy (1979). After normalization, $\delta^{13} \mathrm{C}^{\prime}$ values were more negative in the tissue by $1.0 \pm 0.6 \%$ o $(n=6)$. Values of $\delta^{15} \mathrm{~N}$ were more positive in the tissue by $0.9 \pm 0.9 \%$ o $(n=6)$.
The reason for lower $\delta^{13} \mathrm{C}^{\prime}$ (even after lipid-normalization) and higher $\delta^{15} \mathrm{~N}$ in the tissue compared with the gorgonin is not clear, but may be related to differences in tissue turnover time (Tieszen et al. 1983). Each gorgonin layer integrates seasonal variations over $1 \mathrm{yr}$, and the average isotopic compositions listed in Table 2 integrate inter-annual variations over many years. We expect that the tissue, which turns over in something less than $1 \mathrm{yr}$, represents a unique seasonal signature. Another possibility relates to differences in the amino acid contents of the 2 fractions (O. A. Sherwood unpubl. data). Different amino acids are known to have unique and widely variable $\delta^{13} \mathrm{C}$ (Keil \& Fogel 2001) and $\delta^{15} \mathrm{~N}$ (McClelland \& Montoya 2002); therefore, the relative proportion of amino acids between tissue and gorgonin may indicate differences in stable isotope content.

\section{Geographic and interspecific variability}

There were significant compositional differences among the different species and geographic areas (Table 2). Primnoa pacifica and P. resedaeformis notialis from the Sea of Japan and South Pacific had the lowest tissue $\mathrm{C}$ : $\mathrm{N}$ values $(4.5 \pm 0.4, \mathrm{n}=3)$. $P$. willeyi from the NE Pacific had intermediate C:N $(6.1 \pm 1.4$, $\mathrm{n}=5$ ), and $P$. resedaeformis from the NW Atlantic had the highest $\mathrm{C}: \mathrm{N}(7.5 \pm 0.2, \mathrm{n}=3) . \delta^{13} \mathrm{C}^{\prime}$ and $\delta^{15} \mathrm{~N}$ were

Table 2. Primnoa spp. Summary of stable isotope and C:N data (mean $\pm \mathrm{SD}$ ). $\delta^{13} \mathrm{C}^{\prime}$ : lipid-normalized $\delta^{13} \mathrm{C}_{i}-:$ insufficient material for analysis

\begin{tabular}{|c|c|c|c|c|c|c|c|c|c|c|}
\hline \multirow{2}{*}{ Sample } & \multirow[b]{2}{*}{$\mathrm{n}$} & \multirow[b]{2}{*}{$\mathrm{C}: \mathrm{N}$} & \multirow{2}{*}{$\begin{array}{l}\text { - Tissue } \\
\delta^{13} \mathrm{C}\end{array}$} & \multirow[b]{2}{*}{$\delta^{13} \mathrm{C}^{\prime}$} & \multirow[b]{2}{*}{$\delta^{15} \mathrm{~N}$} & \multirow[b]{2}{*}{$\mathrm{n}$} & \multirow[b]{2}{*}{$\mathrm{C}: \mathrm{N}$} & \multirow{2}{*}{$\begin{array}{l}\text { Gorgonin } \\
\delta^{13} \mathrm{C}\end{array}$} & \multirow[b]{2}{*}{$\delta^{13} C^{\prime}$} & \multirow[b]{2}{*}{$\delta^{15} \mathrm{~N}$} \\
\hline & & & & & & & & & & \\
\hline \multicolumn{11}{|l|}{ NW Atlantic } \\
\hline ROPOS 637052 & 3 & $7.70 \pm 0.47$ & $-23.68 \pm 0.06$ & -21.50 & $10.22 \pm 0.12$ & 16 & - & $-19.15 \pm 0.28$ & $-20.3^{\mathrm{c}}$ & $9.74 \pm 0.15$ \\
\hline ROPOS 639009 & 3 & $7.45 \pm 0.31$ & $-23.92 \pm 0.20$ & -21.82 & $10.12 \pm 0.05$ & 26 & $3.17 \pm 0.04$ & $-19.13 \pm 0.49$ & -20.34 & $9.95 \pm 0.47$ \\
\hline HUD 2000-020-VG2 & - & - & 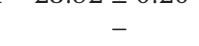 & - & - & 12 & $3.17 \pm 0.05$ & $-19.38 \pm 0.27$ & -20.59 & $9.50 \pm 0.51$ \\
\hline HUD2001-055-VG-15 & - & - & - & - & - & 107 & $3.15 \pm 0.03$ & $-19.01 \pm 0.74$ & -20.25 & $10.13 \pm 0.56$ \\
\hline DFO-2002-con 5 & 5 & $7.25 \pm 0.80$ & $-23.87 \pm 0.30$ & -21.84 & $10.58 \pm 0.31$ & 99 & - & $-19.03 \pm 0.55$ & $-20.18^{\mathrm{c}}$ & $10.28 \pm 0.4$ \\
\hline COHPS2001-1 & - & - & - & - & - & $21^{b}$ & $3.41 \pm 0.10$ & $-17.79 \pm 0.53$ & -18.59 & $10.86 \pm 0.47$ \\
\hline Fossil-95 & - & - & - & - & - & 6 & $3.46 \pm 0.07$ & $-18.29 \pm 0.48$ & -19.01 & $10.99 \pm 0.45$ \\
\hline Smith-54269a & 4 & - & $-20.65 \pm 0.34$ & - & - & 1 & - & -18.35 & $-19.50^{c}$ & 11.8 \\
\hline \multicolumn{11}{|l|}{ NE Pacific } \\
\hline QC-98 & 3 & $7.67 \pm 0.57$ & $-21.17 \pm 0.20$ & -19.00 & $13.26 \pm 0.13$ & 3 & $3.22 \pm 0.04$ & $-17.93 \pm 0.16$ & -19.04 & $12.82 \pm 0.20$ \\
\hline KIS-02 & 1 & 5.73 & -19.42 & -18.05 & 13.80 & 8 & $3.26 \pm 0.06$ & $-16.08 \pm 0.34$ & -17.13 & $12.26 \pm 0.33$ \\
\hline Smith-51283 & 5 & - & $-16.50 \pm 0.38$ & - & - & 2 & - & $-16.17 \pm 0.39$ & $-17.32^{\mathrm{c}}$ & 13.8 \\
\hline Smith-52199 & 1 & 4.06 & -18.24 & -18.17 & 12.53 & _- & - & - & - & - \\
\hline Smith-1010257 & 4 & $6.89 \pm 0.43$ & $-23.77 \pm 0.04$ & -21.87 & $9.09 \pm 0.22$ & - & - & - & - & - \\
\hline Smith-1010785 & 3 & $6.22 \pm 0.23$ & $-19.49 \pm 0.15$ & -17.86 & $12.75 \pm 0.18$ & - & - & - & - & - \\
\hline \multicolumn{11}{|l|}{ Sea of Japan } \\
\hline SOJ-03 & 3 & $4.87 \pm 0.03$ & $-22.45 \pm 0.11$ & -21.64 & $12.91 \pm 0.16$ & 2 & $3.22 \pm 0.02$ & $-19.46 \pm 0.11$ & -20.58 & $10.45 \pm 0.37$ \\
\hline Smith-56993 & 3 & $4.52 \pm 0.05$ & $-21.24 \pm 0.38$ & -20.72 & $10.67 \pm 0.09$ & - & - & - & - & - \\
\hline \multicolumn{11}{|c|}{ S Pacific - Southern Ocean Sector } \\
\hline Smith-58171 & 3 & $4.12 \pm 0.01$ & $-22.05 \pm 0.30$ & -21.91 & $7.76 \pm 0.12$ & 3 & - & - & - & - \\
\hline Smith-87624 & 3 & - & $-21.14 \pm 0.57$ & - & - & 2 & - & $-20.41 \pm 0.45$ & $-21.56^{\mathrm{c}}$ & 7.8 \\
\hline
\end{tabular}



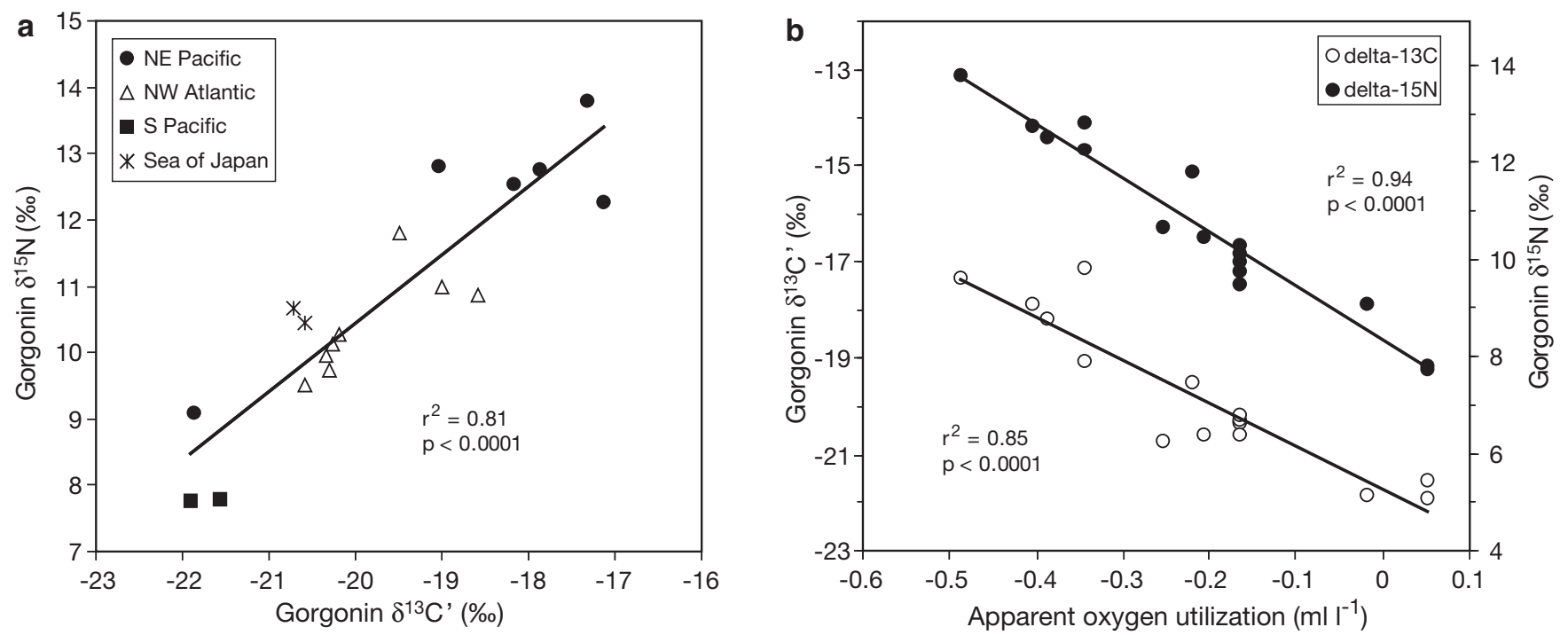

Fig. 4. Primnoa spp. Gorgonin fraction of various colonies showing (a) average $\delta^{15} \mathrm{~N}$ vs. $\delta^{13} \mathrm{C}^{\prime}$ (lipid-normalized $\delta^{13} \mathrm{C}$ ), and (b) average $\delta^{15} \mathrm{~N}$ and $\delta^{13} \mathrm{C}^{\prime}$ as a function of apparent oxygen utilization in surface water. (Note: where gorgonin was not measured, the tissue isotopic values have been plotted instead)

positively correlated ( $\mathrm{p}<0.001$; Fig. $4 \mathrm{a}$ ), as previously found by Heikoop et al. (2002). Isotope values in $\delta^{15} \mathrm{~N}$ vs. $\delta^{13} \mathrm{C}^{\prime}$ space showed clear geographic, trends, with highest values in the NE Pacific, intermediate values in the NW Atlantic and Sea of Japan, and lowest values in the Pacific-Southern Ocean Sector (Fig. 4a). The sample from Atka Island in the NE Pacific (Colony Smith1010257) deviated from this pattern; it had isotope values more similar to the South Pacific samples.

Isotope values were plotted against apparent oxygen utilization (AOU), selected from the Levitus \& Boyer (1994) data set as the best available measure of surface productivity for open ocean, slope water and shelf sites alike (Fig. 4b). Surface water AOU data were obtained from the $0.5^{\circ}$ latitude $\times 0.5^{\circ}$ longitude grid nearest each of the coral collection locations. Both $\delta^{13} \mathrm{C}^{\prime}$ and $\delta^{15} \mathrm{~N}$ significantly increased with increasingly negative AOU (i.e. higher productivity; $\mathrm{p}<0.0001$ ).

\section{Intra-colony isotopic reproducibility}

Specimen HUD2001-055-VG15 Primnoa resedaeformis was the first colony examined for trends in the isotopic composition of annual gorgonin rings. This colony was collected alive and transferred to an aquarium, where the tissue layer eventually died and sloughed off the skeleton. A $50 \mathrm{~cm}$ long main branch was snapped off the colony for geochemical sampling. Sections for stable isotope analyses were cut from the base of the main branch, and from 2 divergent branches $10 \mathrm{~cm}$ higher up the colony (Fig. 2a). The basal section measured $14 \mathrm{~mm}$ in diameter. Stable iso- tope and $\mathrm{C}: \mathrm{N}$ profiles from this specimen are shown in Fig. 5. The $\delta^{13} \mathrm{C}$ profiles were identical among the 3 different sections (correlation coefficients, $r$, ranged 0.84 to $0.97 ; \mathrm{p}<0.0001$ ), showing trends towards heavier values with increasing age. The amplitude of $\delta^{13} \mathrm{C}$ profiles was $3 \%$, much larger than the analytical error $(0.10 \%)$. $\delta^{15} \mathrm{~N}$ profiles were less reproducible between the different sections ( $r=0.38$ to $0.48 ; \mathrm{p}=<0.01$ to 0.05). Differences among coeval rings (up to $1.5 \%$ ) were equivalent to the amplitude of the profiles, and cannot be explained by analytical error. $\mathrm{C}: \mathrm{N}$ profiles were the least reproducible among the different sections ( $\mathrm{r}=-0.23$ to $0.44 ; \mathrm{p}=0.02$ to 0.78 ), with differences among coeval rings (up to 0.07 ) exceeding the analytical error (0.01).

A larger colony of Primnoa resedaeformis (DFO2002-con5) was subsequently obtained from the Canadian Department of Fisheries and Oceans and the same experiment was repeated. This colony was completely covered in live tissue and was frozen immediately after collection (Fig. 2b). Sections for geochemistry were thawed and air dried in the laboratory. The colony measured $70 \mathrm{~cm}$ in length and had a diameter of $26 \mathrm{~mm}$ at the base, which included a thick accumulation of calcite cortex (Fig. 3). Analyses of 5 tissue samples taken along the length of Specimen DFO2002-con5 showed no difference in $\delta^{13} \mathrm{C}$, within analytical error (Fig. 6). The exception was the tissue sample $20 \mathrm{~cm}$ from the top of the colony, which had a value $0.3 \%$ heavier than the rest. $\delta^{15} \mathrm{~N}$ was slightly more variable, with values increasing steadily by $0.8 \%$ from the tip to the base of the colony. $\mathrm{C}: \mathrm{N}$ varied by up to 2 among the different tissue samples. Stable isotope 

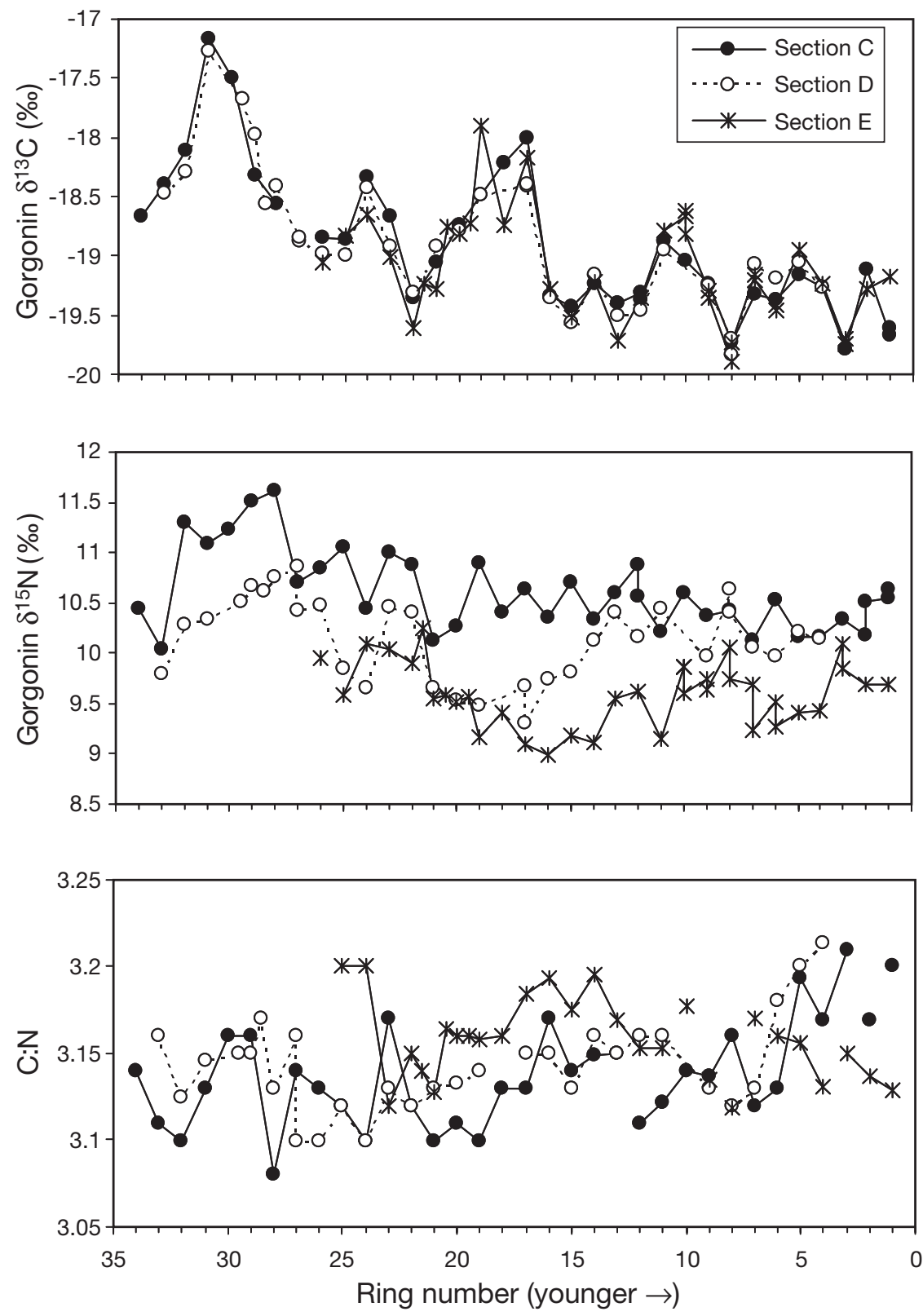

Fig. 5. Primnoa spp. Intra-colony isotopic and C:N profiles from 3 different sections of HUD-2001-055-VG15 (see Fig. 2a for location of sections along colony axis) profiles (Fig. 7) of gorgonin layers were generated from 2 sections at the base of the colony, separated by a distance of $3 \mathrm{~cm}$. C:N was not measured. Isotope profiles were virtually identical among the 2 different sections $\left(r=0.69\left[\delta^{13} \mathrm{C}\right]\right.$ and $\left.0.63\left[\delta^{15} \mathrm{~N}\right] ; \mathrm{p}<0.0001\right)$.

\section{Inter-colony isotopic reproducibility}

Inter-colony isotope reproducibility was assessed among 3 different colonies (Fig. 8). For each colony, ring numbers were converted to calendar ages as described in Sherwood et al. (2005). Briefly, photographic prints of each section were circulated among 3 amateur counters, and the average of the 3 age determinations was calculated. Ring counts were validated by measurements of bomb- ${ }^{14} \mathrm{C}$ in each of the sections (Sherwood et al. 2005). The inter-colony results paralleled intra-colony results, with excellent reproducibility of $\delta^{13} \mathrm{C}$ and poorer reproducibility of $\delta^{15} \mathrm{~N}$ (Fig. 8). Correlation of $\delta^{13} \mathrm{C}$ time-series among the different colonies was highly significant $(\mathrm{r}=0.67$ to $0.86 ; \mathrm{p}<0.0001)$. Correlation of $\delta^{15} \mathrm{~N}$ was significant between Colonies HUD-2001-055-VG15 and ROPOS-639009 ( $r=0.44 ; p<0.05)$, but was insignificant in the other 2 cases.

\section{Comparison of modern and fossil specimens}

The 2 specimens from ca. 200 AD and $1850 \mathrm{AD}$ were compared to other corals collected alive from the NE
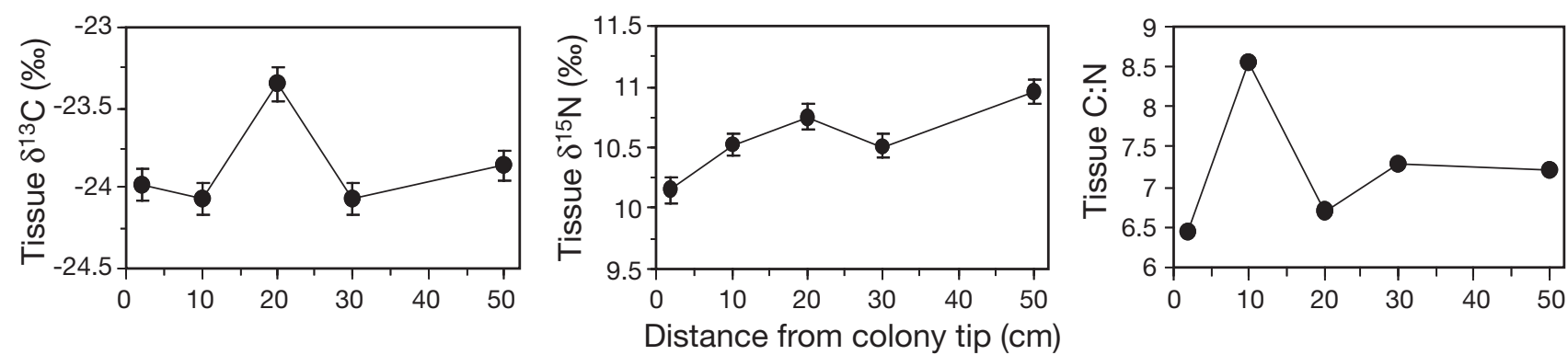

Fig. 6. Primnoa spp. Isotopic and C:N data from the tissue fraction of Colony DFO-2002-con5 (see Fig. 2b for sample locations along colony axis). Error bars are $\pm 1 \mathrm{SD}$ 

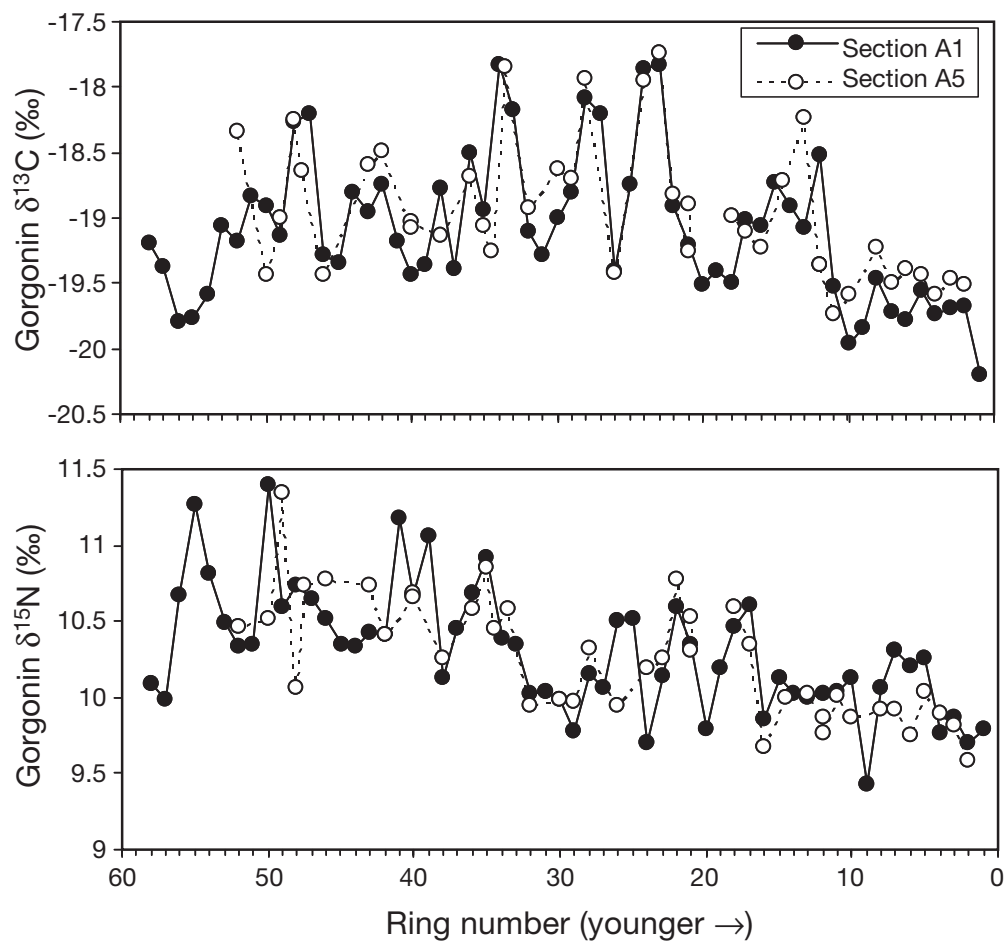

Fig. 7. Primnoa spp. Intra-colony isotopic profiles from 2 different sections of gorgonin layers of Colony DFO-2002-con5 (see Fig. 2b for locations along colony axis)

\section{$\delta^{15} \mathrm{~N}$ composition of plankton}

To assess the trophic level (TL) of Primnoa resedaeformis collected from the $\mathrm{NE}$ Channel (see next subsection), $\delta^{15} \mathrm{~N}$ at the base of the food web was assessed from measurements of $\mathrm{POM}_{\text {susp. Unfortunately, }}$ the NE Channel was not targeted for sampling in the years 2000 to 2003 of the Ecosystems Monitoring Survey (Fig. 1). With the exception of the central shoals of Georges Bank, $\delta^{15} \mathrm{~N}$ in surface water $\mathrm{POM}_{\text {susp }}$ was consistent throughout the entire region $(4.1 \pm 1.2 \%, \mathrm{n}=56$; Fig. 10$)$. We therefore assume that this value is representative of $\mathrm{POM}_{\text {susp }}$ in waters overlying the NE Channel.

In August 2004, the NE Channel was occupied to collect POM susp $_{\text {along a depth }}$ transect (Fig. 1). Below the euphotic zone $\delta^{15} \mathrm{~N}$ increased rapidly to a maximum of $18.5 \%$ at $215 \mathrm{~m}$ depth (Fig. 11). While these data represent only 1 snapshot in time, they are consistent with earlier results reported for Wilkinson Basin, located farther inside the Gulf of Maine (Libes \& Deuser 1988).
Channel (Table 2). C:N ratios of these older specimens, $3.4 \pm 0.1(\mathrm{n}=9)$, were slightly higher than the modern ones, $3.15 \pm 0.05(\mathrm{n}=260)$. The fossil samples were heavier in $\delta^{13} \mathrm{C}^{\prime}$ (lipid normalized to account for difference in $\mathrm{C}: \mathrm{N})$ by $1.5 \%$ (Fig. 9). Part of this difference may be due to the Suess effect, caused by the depletion of atmospheric ${ }^{13} \mathrm{C}$ from the burning of fossil fuels, with subsequent depletion of oceanic dissolved inorganic carbon (DIC; Quay et al. 1992). The 1.5\% difference between the $150 \mathrm{yr}$ old Colony COHPS-2001-1 and the most recent samples from Colony DFO-2002-con5 is consistent with the decrease in atmospheric $\delta^{13} \mathrm{C}$ between the mid-1800s and the present (Francey et al. 1999). The lighter values from ca. 1920, however, exceed the magnitude of the Suess effect. Therefore, there may be other oceanographic and/or trophic level changes affecting $\delta^{13} \mathrm{C}$ over shorter timescales. There was also a slight trend towards higher $\delta^{15} \mathrm{~N}$ with increasing age, with the 2 fossil specimens having values similar to the oldest layers from, Colony DFO-2002-con5 (Fig. 9).
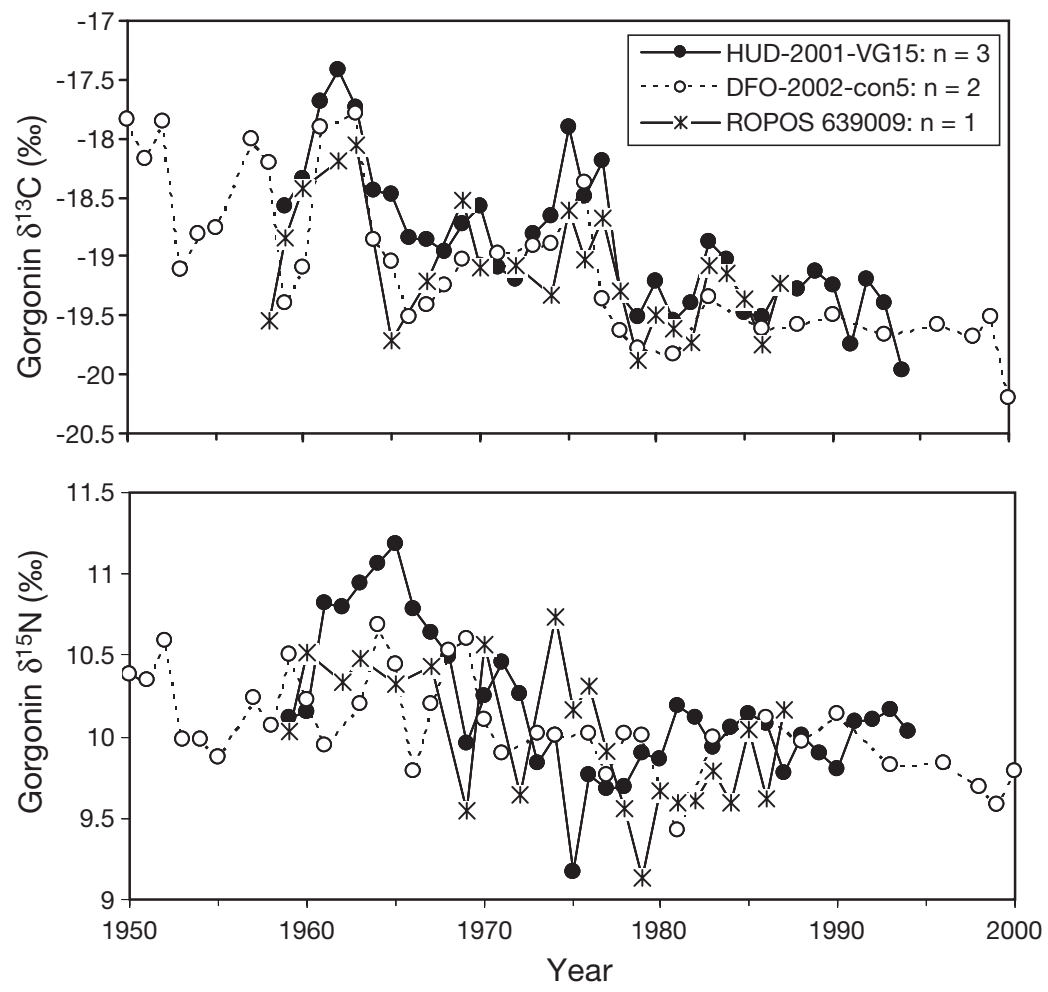

Fig. 8. Primnoa spp. Inter-colony isotopic profiles from 3 different colonies. Chronology based on growth ring counts with bomb- ${ }^{14} \mathrm{C}$ validation (Sherwood et al. 2005). Where $\mathrm{n}$ (no. of sections colony $^{-1}$ analyzed) was $>1$, the average of the profiles is plotted 

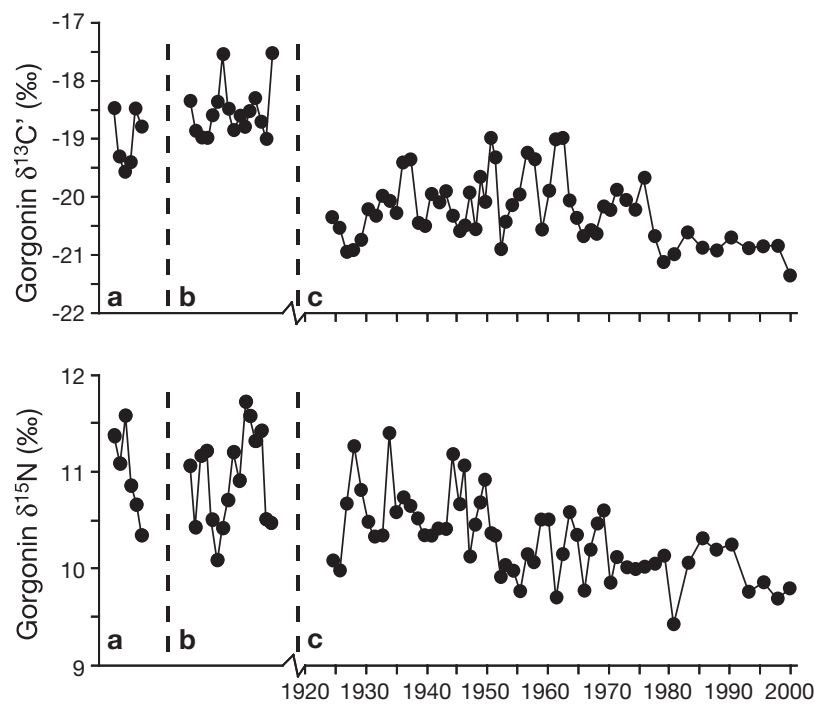

Fig. 9. Primnoa resedaeformis. Isotope profiles from 'fossil' and modern colonies collected from the NE Channel. a: Colony Fossil-95 (ca. 200 AD), b: Colony COHPS-2001-1 (ca. 1850 AD), c: Colony DFO-2002-con5

\section{DISCUSSION}

\section{Trophic level}

It has been demonstrated that deep-sea corals form their organic endoskeletons from sinking POM $\left(\mathrm{POM}_{\text {sink }}\right)$, based on the presence of modern $\Delta^{14} \mathrm{C}$ $(>0 \%$ ) in the gorgonin fraction of their skeletons (Griffin \& Druffel 1989, Heikoop et al. 1998, Roark et al. 2005, Sherwood et al. 2005). Reconstruction of bomb${ }^{14} \mathrm{C}$ from the skeletons of Primnoa resedaeformis collected from the NE Channel (Sherwood et al. 2005) was identical to other proxy records derived from a mollusc shell (Weidman \& Jones 1993) and haddock otoliths (Campana 1997). Moreover, the timing of the initial rise and peak in bomb- ${ }^{14} \mathrm{C}$ was in phase with direct measurements of seawater DIC (Nydal 1998). Therefore,

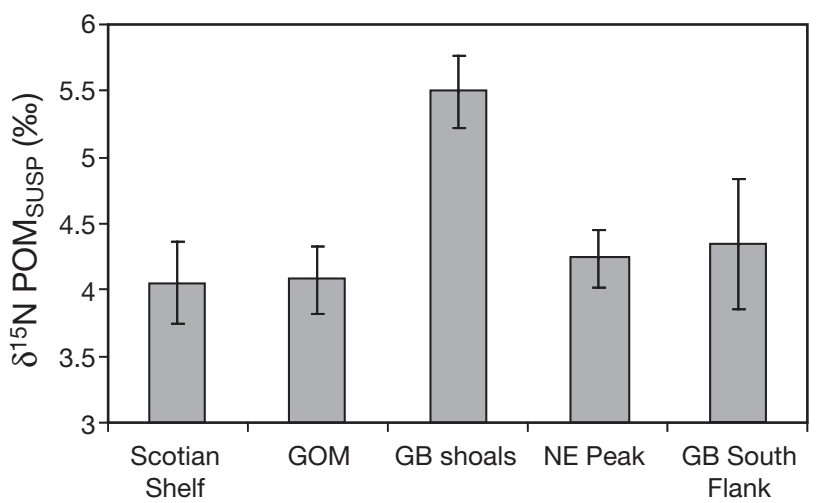

Fig. 10. Average ( $\pm 1 \mathrm{SD}) \delta^{15} \mathrm{~N}$ of $\mathrm{POM}_{\text {susp }}$ in surface waters of the various areas in the Gulf of Maine/Georges Bank region. Site designations as in key to Fig. 1

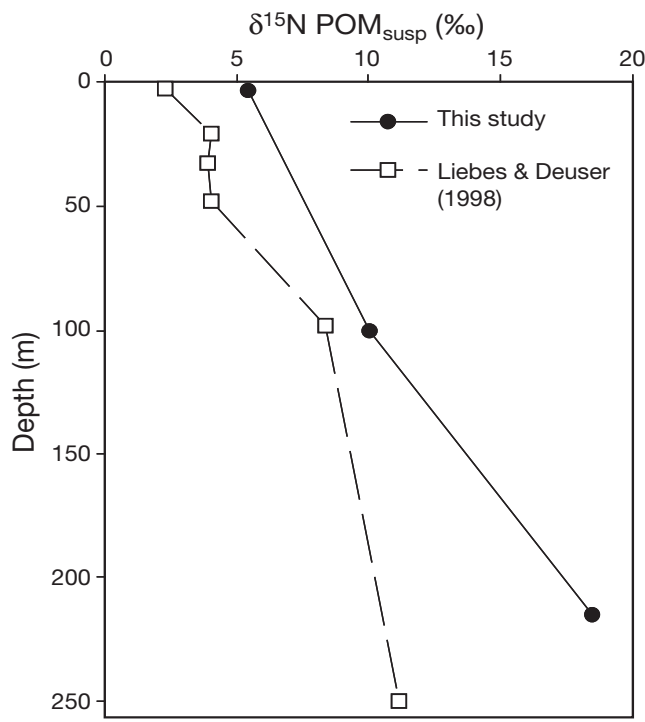

Fig. 11. Depth profile of $\delta^{15} \mathrm{~N}^{\mathrm{POM}}$ susp from NE Channel (this study, see Fig. 1) and from Wilkinson Basin inside the Gulf of Maine (Libes \& Deuser 1988)

the gorgonin fraction is derived from surface water DIC, transmitted to depth via the plankton food web; but these results do not indicate whether Primnoa spp. feed upon sinking phytoplankton, zooplankton or other trophic intermediaries. Because of trophic level fractionation of $\delta^{13} \mathrm{C}$ and $\delta^{15} \mathrm{~N}$, interpretation of time series isotope profiles requires knowledge of the TL.

Further insight into the TL of Primnoa spp. is provided by $\delta^{15} \mathrm{~N}$. This is typically enriched in a consumer relative to its diet by an average enrichment factor of $\Delta \delta^{15} \mathrm{~N}=3.4 \%$ (DeNiro \& Epstein 1981, Minagawa \& Wada 1984, Vander Zanden \& Rasmussen 2001). The TL of Primnoa spp. may therefore be estimated by comparing our data with the isotopic signatures of other organisms of known TL (e.g. Vander Zanden et al. 1997, Polunin et al. 2001). We used primary consumers as the baseline, and calculated TL by the formula: $\mathrm{TL}_{\text {consumer }}=\left(\delta^{15} \mathrm{~N}_{\text {consumer }}-\delta^{15} \mathrm{~N}_{\text {baseline }}\right) / 3.4+2$ (Vander Zanden \& Rasmussen 2001). Wherever possible, we used the gorgonin, rather than tissue results, since these integrate seasonal and inter-annual isotopic variations occurring at the base of the food web. Our approach was to reconstruct regionally-specific TL models from literature data.

Primnoa resedaeformis from the NE Channel was compared with the TL model of Fry (1988), which was based on taxa collected from nearby Georges Bank.

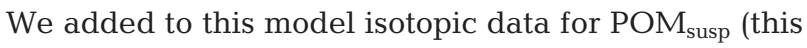
study) $\mathrm{POM}_{\text {sink }}$ (Macko 1981) and size-fractionated zooplankton (Fry \& Quinones 1994). Most of the invertebrates and fish reported in Fry (1988) and Fry \& Quinones (1994) were collected within the $100 \mathrm{~m}$ isobath on Georges Bank, where $\delta^{15} \mathrm{~N}$ of POM $\mathrm{Pusp}_{\text {su }} 1.4 \%$ 
heavier than in surrounding waters (Fig. 10), probably as a result of greater use of regenerated ammonium on the bank (Ostrom et al. 1997, Wu et al. 1999a). We assume that isotopic enrichment on Georges Bank is transmitted to higher trophic levels. This difference in $\delta^{15} \mathrm{~N}$ equates to 0.4 trophic levels and must be accounted for in the TL model output.

The NE Channel/Gulf of Maine $\delta^{15} \mathrm{~N}$-TL model is shown in Fig. 12. We subtracted $1.4 \%$ from the data for the Georges Bank taxa. Herbivorous scallops were used for baseline $\delta^{15} \mathrm{~N}$ (Fry 1988; $6-1.4=4.6 \%$ ). Among live-collected Primnoa resedaeformis from the NE Channel, the inter-colony average $\delta^{15} \mathrm{~N}$ was $10.0 \pm$ $0.3 \%(n=5)$. This value is similar to the $\delta^{15} \mathrm{~N}$ for large benthic isopods, large polychaetes and planktivorous fishes (Fig. 12). The calculated TL is 3.6. This suggests that $P$. resedaeformis is primarily carnivorous. We have also observed that the polyps on $P$. resedaeformis point downwards, suggesting that these corals may also feed on resuspended meiofauna.

Another factor which may affect the TL estimate is isotopic modification of particulate matter in deep waters. Significant enrichment of $\delta^{15} \mathrm{~N}$ below the euphotic zone (Fig. 11) rules out the possibility that Primnoa resedaeformis feeds on the highly degraded $\mathrm{POM}_{\text {susp }}$ encountered at depth (otherwise $\delta^{15} \mathrm{~N}$ in $P$. resedaeformis would be much higher; Fig. 12). $\mathrm{POM}_{\text {sink }}$ may also become isotopically enriched below the euphotic zone, although to a much lesser extent than POM $_{\text {susp }}$ (Altabet 1988, Altabet et al. 1991, Voss et al. 1996). We estimate that $\mathrm{POM}_{\text {sink }}$ in the NE Channel has a $\delta^{15} \mathrm{~N}$ signature of $6.5 \%$ based on sediment data (Macko 1981), and general similarity in $\delta^{15} \mathrm{~N}$ between sediments and $\mathrm{POM}_{\text {sink }}$ (Altabet \& Francois 1994, Voss et al. 1996, Ostrom et al. 1997). Assuming $\Delta \delta^{15} \mathrm{~N}=3.4$, $P$. resedaeformis could feed on $\mathrm{POM}_{\text {sink }}$ as well as zooplankton (Fig. 12).

Heavier $\delta^{15} \mathrm{~N}$ in Primnoa willeyi from the NE Pacific $(12.8 \pm 0.6 \%, \mathrm{n}=5)$, compared to $P$. resedaeformis from the NW Atlantic, may reflect either a difference at the base of the food web or higher TL. We constructed a TL model based on literature $\delta^{15} \mathrm{~N}$ data from 2 inshore Bays near Juneau (Goering et al. 1990) and Prince William Sound, Alaska (Kline 1999; note that 1 of our specimens [Smith-51283] was collected in Prince William Sound). Baseline $\delta^{15} \mathrm{~N}$ was set to $8 \%$, using the values reported for herbivorous copepods (Neocalanus cristatus; Kline 1999) and bivalves (Goering et al. 1990). Overlap in $\delta^{15} \mathrm{~N}$ values among similar taxa from these 2 Alaskan bays, despite a separation of over $600 \mathrm{~km}$, lends confidence that $\delta^{15} \mathrm{~N}$ signatures are well-conserved within the coastal NE Pacific ecosystem. We calculated a TL of about 3.4 for P. willeyi. Measurements of $\mathrm{POM}_{\text {sink }}$ from off Vancouver Island $\left(\delta^{15} \mathrm{~N}=8\right.$ to $9 \%$, Peña et al. 1999 , Wu et al. 1999a) are also consistent with this fraction being a food source for $P$. willeyi. Lighter $\delta^{15} \mathrm{~N}$ in the sample from Atka Island $\left(9.1 \%\right.$ ) may be explained by low $\delta^{15} \mathrm{~N}$ in offshore primary producers (Wu et al. 1997; see next paragraph).

It has been shown that coastal ecosystems often exhibit lower $\Delta \delta^{15} \mathrm{~N}$ than the globally accepted value of $3.4 \%$ (Wu et al. 1997, Sherwood \& Rose 2005). To validate our TL estimates, we also looked at 4 taxa that were sampled in both the NE Pacific and NW Atlantic: euphausiids, bivalves, pollock and sole. TL outputs

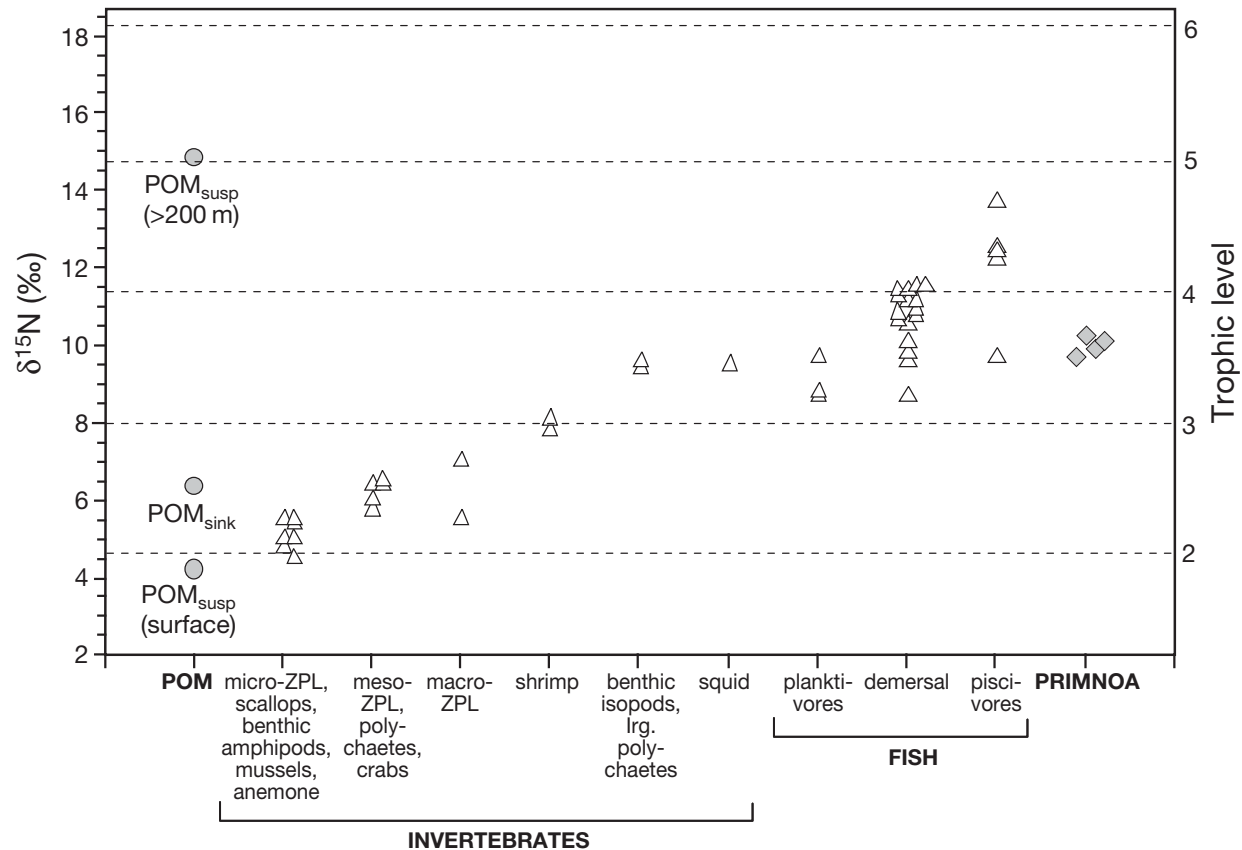

Fig. 12. Trophic level (TL) $-\delta^{15} \mathrm{~N}$ model for the NE Channel/Gulf of Maine region. $(\Delta)$ We subtracted $1.4 \%$ from the data for Georges Bank taxa (data from Fry 1988, Fry \& Quinones 1994) to account for higher $\delta^{15} \mathrm{~N}$ on Georges Bank (see 'Discussion'). (O) Additional data showing surface suspended POM $\left(\right.$ POM $\left._{\text {susp }}\right)$ (this study), deep POM susp (average of data from this study and from Libes \& Deuser 1988) and sinking POM $\left(\mathrm{POM}_{\text {sink }}\right.$ (based on sedimentary $\delta^{15} \mathrm{~N}$ data from Macko 1981). ( $\diamond)$ Primnoa resedaeformis data. TL designations are based on average composition of scallops (TL 2) and $\Delta \delta^{15} \mathrm{~N}=3.4 \%$. ZPL: zooplankton 
for the 2 different ecosystems were statistically equal (matched-pairs $t$-test). Moreover, TL outputs for both ecosystems conformed to expectations: bivalves (TL = 2); euphausiids ( $\mathrm{TL}=2.6$ ); pollock (3.8); sole (3.5 to 3.8). Therefore, our use of $\Delta \delta^{15} \mathrm{~N}=3.4 \%$ or both Georges Bank and coastal NE Pacific ecosystems does not appear to introduce bias in our model outputs.

In summary, isotopic data support the following 3 conclusions about the diet of Primnoa spp. corals: (1) The presence of modern $\Delta^{14} \mathrm{C}$ in Primnoa resedaeformis rules out DOC and DIC as a significant carbon source for the gorgonin fraction of the skeleton (Sherwood et al. 2005. Measurements of $\delta^{15} \mathrm{~N}$ suggest that (2) zooplankton and/or POM sink $_{\text {constitute the main }}$ diet of $P$. resedaeformis and $P$. willeyi, and (3) the highly degraded fraction of $\mathrm{POM}_{\text {susp }}$ found at depth is not a significant food source. This is also supported by the finding that the dark, more gorgonin-rich portion of the annual ring couplets in $P$. resedaeformis co-incides with the timing of the spring/summer bloom of phytoplankton and zooplankton (Sherwood 2002).

Lack of isotopic data for the Sea of Japan and the South Pacific in the literature prevented a similar analysis of the TL of the remaining species. It is quite probable that Primnoa pacifica and P. resedaeformis notialis share a similar type of diet with $P$. resedaeformis and $P$. willeyi, since all the corals have similar-sized polyps.

As passive suspension feeders, octocorals feed opportunistically on a wide spectrum of plankton sizeclasses, from nanoeukaryotes to zooplankton (Ribes et al. 1999, 2003, Orejas et al 2003). Temperate and boreal asymbiotic species feed mainly on zooplankton and detrital POM in about equal proportions, with smaller plankton $(<100 \mu \mathrm{m})$ accounting for $<10 \%$ of energy demand (Ribes et al. 1999, 2003). Among zooplankton, gorgonians ingest smaller, low-motility prey items (Coma et al. 1994, Rossi et al. 2004). Our isotopic data conform to this general pattern, with the exception that the highly degraded POM $_{\text {susp }}$ found at depth does not appear to be a significant food source. Heterogeneity of prey items may explain the differences in the intra- and inter-colony reproducibility of $\delta^{13} \mathrm{C}$ and $\delta^{15} \mathrm{~N}$. It may be possible that different parts of the colony are more effective at capturing different-sized prey items, depending on localized current regimes (Coma et al. 1994). Differential feeding on prey sizeclasses could potentially alter $\delta^{15} \mathrm{~N}$ signatures, due to strong trophic level fractionation of ${ }^{15} \mathrm{~N}$ (Fry \& Quinones 1994). If this is true, then analyses of more sections per colony and more colonies per site are recommended to calculate the average $\delta^{15} \mathrm{~N}$. Since trophic level fractionation of ${ }^{13} \mathrm{C}$ is much weaker (generally $<1 \%$; Vander Zanden \& Rasmussen 2001), differential feeding should exert less influence on $\delta^{13} \mathrm{C}$, thereby lending greater isotopic reproducibility.

\section{Surface-benthic coupling of isotopic signatures}

The overall isotopic signature of a food web is determined by biophysical processes at the level of primary producers. These processes are myriad and complex, especially over shorter timescales. Phytoplankton $\delta^{15} \mathrm{~N}$ mainly depends on the efficiency of nitrogen utilization (Nakatsuka et al. 1992, Altabet \& Francois 1994, Wu et al. 1997, 1999a) and on the $\delta^{15} \mathrm{~N}$ signature of the nitrogenous substrate (Ostrom et al. 1997, Altabet et al. 1999). Phytoplankton $\delta^{13} \mathrm{C}$ mainly depends on $\left[\mathrm{CO}_{2 \mathrm{aq}}\right]$ (Rau et al. 1992, Hoffman et al. 2000), growth rate (Nakatsuka et al. 1992, Hoffman et al. 2000) and cell geometry/plankton species composition (Fry \& Wainright 1991, Popp et al. 1998), as well as the $\delta^{13} \mathrm{C}$ signature of the bicarbonate substrate (Cullen et al. 2001). As a result of these myriad factors, there are large isotopic differences between open ocean, slope water and coastal ecosystems (Wu et al. 1997). Furthermore, different pathways of isotopic fractionation often lead to decoupling of $\delta^{13} \mathrm{C}$ and $\delta^{15} \mathrm{~N}$ in new production (Ostrom et al. 1997, Wu et al. 1999a,b). In Fig. 4b, our use of surface water AOU is not meant to imply control on isotopic fractionation, but to give some sense of the different surface productivity regimes where the corals lived. The lightest values were found in the South Pacific, located near a high-nutrient low-chlorophyll (HNLC) domain, where despite high $\left[\mathrm{NO}_{3}\right]$ and $\left[\mathrm{CO}_{2}\right]$, primary production is limited by micronutrients such as iron. Similarly low values were observed in a specimen from Atka Island, in the Aleutian Islands, also located near an HNLC domain (Wu et al. 1999b). Heavier values were found in the slope water regions of the NW Atlantic and the Sea of Japan, where primary productivity is typically dominated by blooms of large, fast-growing phytoplankton (Mousseau et al. 1996). These blooms lead to nutrient depletion and heavier $\delta^{13} \mathrm{C}$ and $\delta^{15} \mathrm{~N}$ values. The heaviest values were in corals from Alaska and British Columbia, consistent with highest productivity rates in these coastal domains. These results demonstrate that isotopic signatures originating from primary producers are transmitted to, and preserved within, the organic endoskeletons of Primnoa spp. It is therefore not surprising that $\delta^{13} \mathrm{C}$ and $\delta^{15} \mathrm{~N}$ in Primnoa spp. are both so tightly correlated with AOU (Fig. 4b).

\section{Preservation of original isotopic composition}

For isotopic trends from gorgonin to have any paleoceanographic utility, there must not be any diagenetic overprinting. In many of the fossil specimens donated to us by fishermen, the gorgonin appeared to be more susceptible to degradation than the inorganic calcite cortex fraction. On the broken axes of these dead colonies, the 
inner horny axis is often worn down in a smooth cupshaped depression, while the cortex remains intact. Similarity in C:N, $\delta^{13} \mathrm{C}$ and $\delta^{15} \mathrm{~N}$ between modern and fossil specimens suggests that isotopic signatures are preserved from the time of original formation. This is also supported by identical amino acid abundances between modern and fossil specimens (O. A. Sherwood unpubl.), since diagenesis often leads to the synthesis of microbial biomass of different amino acid and stable isotope composition (Macko \& Estep 1984). The degradation observed in fossil specimens appears to be the result of mechanical erosion, probably by the action of suspended sands, rather than organic diagenesis. This finding is consistent with gorgonin being one of the most chemically inert proteins known (Goldberg 1976). Over millennial timescales, therefore, isotope abundances in Primnoa spp. are preserved, making these corals durable archives of paleoceanographic information.

\section{Paleoceanographic applications}

Owing to little trophic level fractionation and excellent intra- and inter-colony reproducibility, $\delta^{13} \mathrm{C}$ timeseries from Primnoa spp. could reliably track variations in surface processes. From Fig. 8, it appears that the 3 colonies of $P$. resedaeformis from the NE Channel recorded a peak in $\delta^{13} \mathrm{C}$ around the mid-twentieth century, with several decade-scale oscillations. The causes of these variations are not clear, but there may be an important link with known changes in plankton community composition since the 1960s in this region (Sameoto 2001). On the other hand, evidence of the oceanic Suess effect on the $\delta^{13} \mathrm{C}$ composition of modern vs. fossil specimens (Fig. 9), and reconstruction of 20th century bomb radiocarbon (Sherwood et al. 2005) are examples of isotopic variability in source materials recorded in these corals. Therefore, there is evidence that both biological processes (i.e. correlation of $\delta^{13} \mathrm{C}$ and $\delta^{15} \mathrm{~N}$ with AOU) and physical processes (changes in isotopic composition of bicarbonate substrate) are reflected in gorgonin isotope content. Smaller regional studies with multiple colonies and good chronological control will be required to deconvolute these different factors. Useful information may also be extracted from $\delta^{15} \mathrm{~N}$ profiles, provided that time-series variability is large relative to the intra- and inter-colony variability.

The annual nature of ring formation makes Primnoa spp. analogous to varved sediment cores, from which much useful paleoceanographic information has been retrieved (e.g. Tunnicliffe 2000). In similar fashion, annually resolved isotope time-series have been generated from preserved animal remains, such as fish scales (Wainright et al. 1993) and whale baleen (Schell 2001). Long lifespans (at least 400 yr, probably longer;
Risk et al. 2002) lend to Primnoa spp. the advantages of both varved sediment cores (longer, in situ time-series) and preserved animal remains (widespread distribution, known TL). Isotopic reconstructions from Primnoa spp. could be useful in illustrating temporal variations in marine productivity, as well as tracking the relative importance of top-down vs. bottom-up influences over time (Schell 2001, Satterfield \& Finney 2002, Rau et al. 2003). Oceanographic phenomena that may be recorded include changes in the position of water mass boundaries, upwelling strength, terrestrial nutrient inputs and atmospheric nutrient inputs.

Deep-sea corals could prove to be temporal and spatial recorders of the efficacy of the oceanic biological pump that transfers carbon dioxide from the atmosphere to the deep-ocean. By understanding natural processes that have affected the operation of this pump over century timescales, we can better predict the effects of global change and potential engineered approaches such as iron fertilization on oceanic carbon sequestration. The widespread occurrence and diversity of deep-sea corals is only now being fully appreciated. As more deep-sea corals are discovered in important oceanographic regions the applicability of this potential paleoceanographic archive is likely to increase.

\section{CONCLUSIONS}

Measurements of $\delta^{15} \mathrm{~N}$ indicate that Primnoa resedaeformis and $P$. willeyi have a TL of about 3.5. POM $\mathrm{Pink}_{\text {sin }}$ and zooplankton appear to constitute the bulk of their diet, whereas DIC, DOC and POM ${ }_{\text {susp }}$ are not consumed. The TL for $P$. pacifica and $P$. resedaeformis notialis could not be determined but, based on similar sized polyps, it is likely that these species feed at a similar TL.

Average $\delta^{13} \mathrm{C}$ and $\delta^{15} \mathrm{~N}$ compositions of the gorgonin fraction were strongly correlated with each other and with surface water AOU. This demonstrates strong coupling between surface biophysical processes and stable isotope compositions in Primnoa spp.

Isotope profiles from annual gorgonin rings showed excellent intra-colony and inter-colony reproducibility for $\delta^{13} \mathrm{C}$, while for $\delta^{15} \mathrm{~N}$ the reproducibility was not as good. The latter result may arise from differential feeding upon different sized prey items, depending on localized current regimes; however, more work is needed to address this issue.

Similarity in $\mathrm{C}: \mathrm{N}, \delta^{13} \mathrm{C}$ and $\delta^{15} \mathrm{~N}$ between modern and fossil specimens demonstrates a lack of organic diagenesis in the tough gorgonin fraction. Isotopic signatures from the time of formation are therefore preserved over millennial timescales, making these corals excellent candidates for retrospective studies of the surface marine environment. 
Acknowledgements. For providing coral samples, we are thankful to S. Atwood, L. Buhl Mortensen, S. Cairns, D. Gordon, D. Jones, D. Mackas, P. Mortensen, A. Muir, L. Talley, V. Tunnicliffe, and R. Wolkins. J. McKay performed isotopic analyses at GEOTOP. We are grateful to B. Ghaleb for providing radiometric dates. Stable isotopic analyses at UNM were performed by V. Atudorei, M. Hess, and Z. Sharp. We thank Jerry Prezioso of NOAA NMFS, Narragansett, Rhode Island, for kindly providing POM samples. Lawrence Plug offered valuable help with digital mapping. We also thank 3 anonymous reviewers for suggestions leading to improvement of this manuscript. Funding was provided by an NSERC Strategic Grant to M.J.R. and D.B.S., an Institute of Geophysics and Planetary Physics, Los Alamos National Laboratory, grant to J.M.H., and an NSERC postgraduate scholarship to O.A.S. Radiocarbon analyses were performed under the auspices of the US Department of Energy by the University of California Lawrence Livermore National Laboratory (contract W-7405-Eng-48).

\section{LITERATURE CITED}

Altabet MA (1988) Variations in nitrogen isotopic composition between sinking and suspended particles: implications for nitrogen cycling and particle transformation in the open ocean. Deep-Sea Res 35:535-554

Altabet MA, Francois R (1994) Sedimentary nitrogen isotopic ratio as a recorder for surface ocean nitrate utilization. Global Biogeochem Cycles 8:103-116

Altabet MA, Deuser WG, Honjo S, Stienen C (1991) Seasonal and depth-related changes in the source of sinking particles in the North Atlantic. Nature 354:136-139

Altabet MA, Pilskaln C, Thunell RC, Pride C, Sigman D, Chavez F, Francois R (1999) The nitrogen isotope biogeochemistry of sinking particles from the margin of the Eastern North Pacific. Deep-Sea Res 46:655-679

Andrews AH, Cordes EE, Mahoney MM, Munk K, Coale KH, Cailliet GM, Heifetz J (2002) Age, growth and radiometric age validation of a deep-sea, habitat-forming gorgonian (Primnoa resedaeformis) from the Gulf of Alaska. Hydrobiologia 471:101-110

Bosley KL, Wainright SC (1999) Effects of preservation and acidification on the stable isotope ratios $\left({ }^{15} \mathrm{~N}:{ }^{14} \mathrm{~N},{ }^{13} \mathrm{C}:{ }^{12} \mathrm{C}\right)$ of 2 species of marine animals. Can J Fish Aquat Sci 56: 2181-2185

Breeze H, Davis DS, Butler M, Kostylev V (1997) Distribution and status of deep-sea corals off Nova Scotia. Spec Publ 1. Marine Issues Committee, Ecology Action Centre, Halifax, NS

Campana SE (1997) Use of radiocarbon from nuclear fallout as a dated marker in the otoliths of haddock Melanogrammus aeglefinus. Mar Ecol Prog Ser 150:49-56

Coma R, Gili JM, Zabala M, Riera T (1994) Feeding and prey capture cycles in the aposymbiotic gorgonian Paramuricea clavata Mar Ecol Prog Ser 115:257-270

Cullen JT, Rosenthal Y, Falkowski PG (2001) The effect of anthropogenic $\mathrm{CO}_{2}$ on the carbon isotope composition of marine phytoplankton. Limnol Oceanogr 46:996-998

DeNiro MJ, Epstein S (1981) Influence of diet on the distribution of nitrogen isotopes in animals. Geochim Cosmochim Acta 45:341-351

Druffel ERM, Griffin S, Witter A, Nelson E, Southon J, Kashgarian M, Vogel J (1995) Gerardia: Bristlecone pine of the deep-sea? Geochim Cosmochim Acta 59: 5031-5036

Etnoyer P, Morgan L (2003) Occurrences of habitat-forming deep sea corals in the Northeast Pacific Ocean. Report to NOAA Office of Habitat Conservation. Marine Conservation Biology Institute, Redmond, WA

Francey RJ, Allison CE, Etheridge DM, Trudinger CM and 5 others (1999) A 1000 year high precision record of $\delta^{13} \mathrm{C}$ in atmospheric $\mathrm{CO}_{2}$. Tellus 51B:170-193

Fry B (1988) Food web structure on Georges Bank from stable C, N, and S isotopic compositions. Limnol Oceanogr 33: $1182-1190$

Fry B, Quinones RN (1994) Biomass spectra and stable isotope indicators of trophic level in zooplankton of the northwest Atlantic. Mar Ecol Prog Ser 112:201-204

Fry B, Wainright SC (1991) Diatom sources of ${ }^{13}$ C-rich carbon in marine food webs. Mar Ecol Prog Ser 76:149-157

Goering J, Alexander V, Haubenstock N (1990) Seasonal variability of stable carbon and nitrogen isotope ratios of organisms in a North Pacific bay. Estuar Coast Shelf Sci 30:239-260

Goldberg WM (1976) Comparative study of the chemistry and structure of gorgonian and antipatharian coral skeletons. Mar Biol 35:253-267

Griffin SM, Druffel ERM (1989) Sources of carbon to deep-sea corals. Radiocarbon 31:533-543

Heikoop JM, Risk MJ, Schwarcz HP (1998) Stable isotopes of $\mathrm{C}$ and $\mathrm{N}$ in tissue and skeletal organics of a deep-sea gorgonian coral from the Atlantic coast of Canada: dietary and potential climate signals. Geol Soc Am Abstr Annu Meet 30(7): A317

Heikoop JM, Hickmott DD, Risk MJ, Shearer CK, Atudorei V (2002) Potential climate signals from the deep-sea gorgonian coral Primnoa resedaeformis. Hydrobiologia 471: $117-124$

Hoffman M, Wolf-Gladrow DA, Takahashi T, Sutherland SC, Six KD, Maier-Reimer E (2000) Stable carbon isotope distribution of particulate organic matter in the ocean: a model study. Mar Chem 72:131-150

Keil RG, Fogel ML (2001) Reworking of amino acid in marine sediments: stable carbon isotopic composition of amino acids in sediments along the Washington coast. Limnol Oceanogr 46:14-23

Kline TC (1999) Temporal and spatial variability of ${ }^{13} \mathrm{C} /{ }^{12} \mathrm{C}$ and ${ }^{15} \mathrm{~N} /{ }^{14} \mathrm{~N}$ in pelagic biota of Prince William Sound, Alaska. Can J Fish Aquat Sci 56(Suppl 1):94-117

Levitus S, Boyer T (1994) World Ocean atlas 1994, Vol 2. Oxygen. NOAA Atlas NESDIS 2, US Department of Commerce, Washington, DC

Libes SM, Deuser WG (1988) The isotope geochemistry of particulate nitrogen in the Peru upwelling area and the Gulf of Maine. Deep-Sea Res 35:517-533

Macko SA (1981) Stable nitrogen isotope ratios as tracers of organic geochemical processes. PhD thesis, University of Texas, Austin, TX

Macko SA, Estep ML (1984) Microbial alteration of stable nitrogen and carbon isotopic compositions of organic matter. Org Geochem 6:787-790

McClelland JW, Montoya JP (2002) Trophic relationships and the nitrogen isotopic composition of amino acids in plankton. Ecology 83:2173-2180

McConnaughey T, McRoy CP (1979) Food web structure and the fractionation of carbon isotopes in the Bering Sea. Mar Biol 53:257-262

Minagawa M, Wada E (1984) Stepwise enrichment of $\delta^{15} \mathrm{~N}$ along food chains: further evidence and the relation between ${ }^{15} \mathrm{~N}$ and animal age. Geochim Cosmochim Acta 48:1135-1140

Mousseau L, Legendre L, Fortier L (1996) Dynamics of sizefractionated phytoplankton and trophic pathways on the 
Scotian Shelf and at the shelf break, Northwest Atlantic. Aquat Microb Ecol 10:149-163

Nakatsuka T, Handa N, Wada E, Wong CS (1992) The dynamic changes of stable isotopic ratios of nitrogen and carbon in suspended and sedimented particulate organic matter during a phytoplankton bloom. J Mar Res 50: 267-296

Nydal R (1998) Carbon-14 measurements in surface water $\mathrm{CO}_{2}$ from the Atlantic, Indian and Pacific Oceans, 1965-1994. ORNL/CDIAC-104, NDP-057A. Carbon Dioxide Information Analysis Center, Oak Ridge National Laboratory, Oak Ridge, TN

Orejas C, Gili JM, Arntz W (2003) Role of small-plankton communities in the diet of 2 Antarctic octocorals (Primnoisis antarctica and Primnoella sp.). Mar Ecol Prog Ser 250:105-116

Ostrom NE, Macko SA, Deibel D, Thompson RJ (1997) Seasonal variation in the stable carbon and nitrogen isotope biogeochemistry of a coastal cold ocean environment. Geochim Cosmochim Acta 61:2929-2942

Peña MA, Denman KL, Calvert SA, Thomson RE, Forbes JR (1999) The seasonal cycle in sinking particle fluxes off Vancouver Island, British Columbia. Deep-Sea Res II 46: 2969-2992

Polunin NVC, Morales-Nin B, Pawsey WE, Cartes JE, Pinnegar JK, Moranta J (2001) Feeding relationships in Mediterranean bathyal assemblages elucidated by stable nitrogen and carbon isotope data. Mar Ecol Prog Ser 220: $13-23$

Popp BN, Laws EA, Bidigare RR, Dore JE, Hanson KL, Wakeham SG (1998) Effect of phytoplankton cell geometry on carbon isotopic fractionation. Geochim Cosmochim Acta 62(1):69-77

Quay PD, Tilbrook B, Wong CS (1992) Oceanic uptake of fossil fuel $\mathrm{CO}_{2}$ : carbon-13 evidence. Science 256: $74-79$

Rau GH, Takahashi T, Des Marais DJ, Repeta DJ, Martin JH (1992) The relationship between $\delta^{13} \mathrm{C}$ of organic matter and $\left[\mathrm{CO}_{2}(\mathrm{aq})\right]$ in ocean surface water: data from a JGOFS site in the northeast Atlantic Ocean and a model. Geochim Cosmochim Acta 56:1413-1419

Rau GH, Ohman MD, Pierrot-Bults A (2003) Linking nitrogen dynamics to climate variability off central California: a 51 year record based on ${ }^{15} \mathrm{~N} /{ }^{14} \mathrm{~N}$ in CalCOFI zooplankton. Deep-Sea Res II 50:2431-2447

Ribes M, Coma R, Gili JM (1999) Heterogenous feeding in benthic suspension feeders: the natural diet and grazing rate of the temperate gorgonian Paramuricea clavata (Cnidaria: Octocorallia) over a year cycle. Mar Ecol Prog Ser 183:125-137

Ribes M, Coma R, Rossi S (2003) Natural feeding of the temperate asymbiotic octocoral-gorgonian Leptogorgia sarmentosa. Mar Ecol Prog Ser 254:141-150

Risk MJ, Heikoop JM, Snow MG, Beukens R (2002) Lifespans and growth patterns of two deep-sea corals: Primnoa resedaeformis and Desmophyllum cristigalli. Hydrobiologia 471:125-131

Roark EB, Guilderson TP, Flood-Page S, Dunbar RB, Ingram BL, Fallon SJ, McCulloch M (2005) Radiocarbon-based ages and growth rates of bamboo corals from the Gulf of Alaska. Geophys Res Lett 32:L04606.doi:10.1029/2004 GL021919

Rossi S, Ribes M, Coma R, Gili JM (2004) Temporal variability in zooplankton prey capture rate of the passive suspension

Editorial responsibility: Otto Kinne (Editor-in-Chief), Oldendorf/Luhe, Germany feeder Leptogorgia sarmentosa (Cnidaria: Octocorallia), a case study. Mar Biol 144:89-99

Sameoto D (2001) Decadal changes in phytoplankton color index and selected calanoid copepods in continuous plankton recorder data from the Scotian Shelf. Can J Fish Aquat Sci 58:749-761

Satterfield FR IV, Finney BP (2002) Stable isotope analysis of Pacific salmon: insight into trophic status and oceanographic conditions over the last 30 years. Prog Oceanogr 53:231-246

Schell DM (2000) Declining carrying capacity in the Bering Sea: isotopic evidence from whale baleen. Limnol Oceanogr 45:459-462

Sherwood OA (2002) The deep-sea gorgonian coral Primnoa resedaeformis as an oceanographic monitor. MSc thesis, McMaster University, Hamilton, ON

Sherwood GD, Rose GA (2005) Stable isotope analysis of some representative fish and invertebrates of the Newfoundland and Labrador continental shelf food web. Estuar Coast Shelf Sci 63:537-549

Sherwood OA, Scott DB, Risk MJ, Guilderson TP (2005) Radiocarbon evidence for annual growth rings in the deep-sea octocoral Primnoa resedaeformis. Mar Ecol Prog Ser 301:129-134

Tieszen LL, Boutton TW, Tesdahl KG, Slade NA (1983) Fractionation and turnover of stable carbon isotopes in animal tissues: implications for ${ }^{13} \mathrm{C}$ analysis of diet. Oecologia 57: $32-37$

Tunnicliffe V (2000) A fine-scale record of 130 years of organic carbon deposition in an anoxic fjord, Saanich Inlet, British Columbia. Limnol Oceanogr 45:1380-1387

Vander Zanden MJ, Rasmussen JB (2001) Variation in $\delta^{15} \mathrm{~N}$ and $\delta^{13} \mathrm{C}$ trophic fractionation: implications for aquatic food web studies. Limnol Oceanogr 46:2061-2066

Vander Zanden MJ, Cabana G, Rasmussen JB (1997) Comparing trophic position of freshwater fish calculated using stable nitrogen isotope ratios $\left(\delta^{15} \mathrm{~N}\right)$ and literature dietary data. Can J Fish Aquat Sci 54:1142-1158

Voss M, Altabet MA, Bodungen BV (1996) $\delta^{15} \mathrm{~N}$ in sedimenting particles as indicator of euphotic zone processes. Deep-Sea Res I 43:33-47

Wainright SC, Fogarty MJ, Greenfield RC, Fry B (1993) Longterm changes in the Georges Bank food web: trends in stable isotopic compositions of fish scales. Mar Biol 115: 481-493

Ward-Paige CA, Risk MJ, Sherwood OA (2005) Reconstruction of nitrogen sources on coral reefs: $\delta^{15} \mathrm{~N}$ and $\delta^{13} \mathrm{C}$ in gorgonians from the Florida Reef Tract. Mar Ecol Prog Ser 296:155-163

Weidman CR, Jones GA (1993) A shell-derived time history of bomb ${ }^{14} \mathrm{C}$ on Georges Bank and its Labrador Sea implications. J Geophys Res C 98:14577-14588

Wu J, Calvert SE, Wong CS (1997) Nitrogen isotope variations in the subarctic northeast Pacific: relationships to nitrate utilization and trophic structure. Deep-Sea Res I 44: 287-314

Wu J, Calvert SE, Wong CS (1999a) Carbon and nitrogen isotope ratios in sedimenting particulate organic matter at an upwelling site off Vancouver Island. Estuar Coast Shelf Sci 48:193-203

Wu J, Calvert SE, Wong CS, Whitney FA (1999b) Carbon and nitrogen isotopic composition of sedimenting particulate material at Station Papa in the subarctic northeast Pacific. Deep-Sea Res II 46:2793-2832

Submitted: October 21, 2004; Accepted: April 21, 2005

Proofs received from author(s): September 5, 2005 